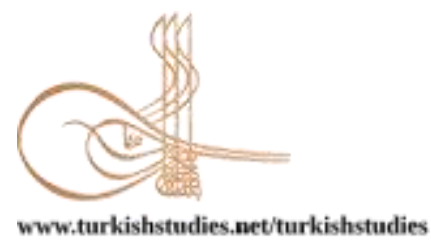

Turkish Studies

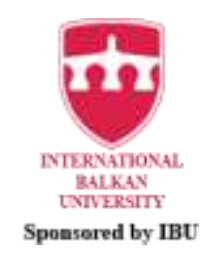

Research Article / Araştırma Makalesi

\title{
Dinamik Matematik Öğrenme Nesnelerinin Türkiye ve İran Lise Öğrencilerinin Akademik Başarılarına, Tutumlarına ve Derse Katılımlarına Etkisi (Nicel Bir Çalışma)
}

\author{
Dynamic Mathematics Learning Objects, Turkey and Iran 10th Grade Students on Academic \\ Success, Impact of Attendance and Attitude (A Quantitative Study)
}

\author{
Ali Babapour Golezani* - Aslan Gülcï ${ }^{* *}$
}

\begin{abstract}
In this study, Turkey and Iran 10th grade students of the quadratic equation unit designed for dynamic mathematics Mathematics Learning Objects (DMLO's); It is aimed to examine the effect of students' academic achievements, attitudes and participation in the lesson. In addition, the impact on students in math class considering the use of dmlo training conditions in Turkey and Iran were compared. For this purpose, the quasi-experimental design in quantitative research methods was used in the study. Academic achievement test, attitude and class participation scale were used to collect data in the study. In the study, Academic achievement test, attitude and class participation scale were used to collect data. Mann-Whitney U test and Wilcoxon signed rank test were used to analyze quantitative data. The study, designed as a pretestposttest quasi-experimental design with experimental and control groups, was conducted with 112 students. The participants of the study, students 56 from Shaheed Mehdi Salek High School in the city of Tabriz in Iran (28 experimental group and 28 students in the control group) and 56 students in Erzurum Province of Mehmet Akif Ersoy High School in Turkey (28 students in the experimental group and 28 students in the control group) is created. Considering the analysis of the data obtained from the 6-week study result; dmlo studying with Turkey and academic achievement scores of students from the experimental group, Iran has appeared to be more than the control group. It is also noted that there is a significant difference between attitude and class participation of students in the experimental group scores Turkey and Iran. Both countries (Iran and Turkey) 10th grade students as a result of the use of mathematics in the course dmlo, academic achievement, attitudes and attendance appeared to be affected in a positive way. The data of the study belongs to 2019-2020.
\end{abstract}

Structured Abstract: The most important reason for the difficulties encountered in teaching and learning mathematics is that mathematics is an abstract lesson (Frenkel, 2013; Patadia \& Ramani, 2012; Sarama \& Clements, 2009). It is thought that computer technology will contribute to the elimination of such difficulties and the development of high-level learning skills by visualizing the materials (Baki, 2002). Important steps are being taken to integrate computers into different areas of education and to embody abstract lesson subjects, especially mathematics, by using this technology. In this direction, it is now indispensable to

\footnotetext{
* Dr., Atatürk Üniversitesi, Kazım Karabekir Eğitim Fakültesi, Bilgisayar ve Öğretim Teknolojileri Eğitimi Dr., Ataturk University, Department of Computer Education and Instructional Technology ORCID 0000-0001-5958-5056

alibabapur1983@gmail.com

** Prof. Dr., Atatürk Üniversitesi, Kazım Karabekir Eğitim Fakültesi, Bilgisayar ve Öğretim Teknolojileri Eğitimi Prof. Dr., Ataturk University, Department of Computer Education and Instructional Technology ORCID 0000-0001-6857-7760 aslangulcu@gmail.com

Cite as/ Atıf: Golezani, B. A. \& Gülcü, A (2021). Dinamik matematik öğrenme nesnelerinin Türkiye ve İran lise ögrencilerinin akademik başarılarına, tutumlarına ve derse katılımlarına etkisi (nicel bir çalışma). Turkish Studies, 16(2), 651-673. https://dx.doi.org/10.7827/TurkishStudies.49445

Received/Geliş: 15 February/Şubat 2021

Accepted/Kabul: 25 April/Nisan 2021

Checked by plagiarism software

Published/Yayın: 30 April/Nisan 2021

CC BY-NC 4.0
} 
develop new learning environments so that students can learn by discovering information. Students visually learn mathematics subjects through computers in new learning environments and reach a deep and permanent learning level by constantly solving new problems to improve themselves (Tutak, Türkdoğan \& Birgin, 2009).

One of the topics that are very difficult to explain for teachers and cause misconceptions on students in the mathematics curriculum is the issue of quadratic equations (Bell \& Janvier, 1981; Capraro et al., 2005; Dunham \& Osborne, 1991; Even, 1998; Kieran, 1992; Kutluca \& Baki, 2009; Leinhardt et al., 1990; Tatar et al., 2008; Zazkis, Liljedahl \& Gadowsky, 2003).

Teachers' use of classical methods while explaining these subjects causes students to encounter abstract concepts and have difficulties in understanding this subject (Aşkar \& Işıksal, 2003). Explaining these abstract issues is also a challenge, not only for students but also for teachers. In order to overcome these difficulties, it is thought that the subject should be explained to students in a three-dimensional environment by visualizing (Lannie \& Martens, 2004; Uğurel \& Bukova-Güzel, 2010). In order to embody this abstract structure and present it to the learner in the form of a visual material, it is necessary to emphasize the importance of needing software that includes mathematical subjects, especially information technology tools.

The aim of this study, is to explain the use of Dynamic Mathematics Learning Objects (DMLO's) in the explanation of the second order equations unit of 10th grade mathematics lesson; It is to examine the effect of students' academic achievement, attitudes and participation in the lesson. Also taking into account the educational requirements of Turkey and Iran, the impact on students of 10th grade students of the use of dmlo in math class were compared.

In this direction; The following questions were sought regarding the use of DMLO's prepared with the Wolfram Mathematica program.

*In terms of the effect of DMLO on the academic success of students:

a. Is there a significant difference between the experimental and control groups?

b. Is there significant difference between Turkey and Iran experimental groups?

* In terms of DMLO's attitudes of students towards mathematics lesson;

a. Is there a significant difference between experimental group pretest-posttest scores?

b. Is there significant difference between Turkey and Iran experimental groups?

* In terms of the effect of DMÖN on students' participation in the lesson;

a. Is there a significant difference between experimental group pretest-posttest scores?

b. Is there significant difference between Turkey and Iran experimental groups?

The use of new technologies in educational settings means that they address more sensory organs at the same time. It is thought that education will become more enjoyable and permanent as a result of the visualization of educational materials by technological tools, especially computers (Tosun, 2006). The fact that the use of tablets, mobile devices and computer games has become a habit of students due to the living conditions causes technology to create a positive effect in the classroom environment (Adıgüzel, Gürbulak \& Sarıçayır, 2011; Çubukçu \& Demircan, 2019; Zbiek et al., 2007). It is of particular importance for students to learn the use of digital technologies so that they can achieve high-level thinking, be innovative and socialize while participating in group work (Çakıroglu, Sarı \& Akkan, 2011; Günüç, Odabaşı \& Kuzu, 2013).

In researches on the use of technology in education, integrating technology in education increases students' motivation, provides access to various information resources, supports collaborative learning (Peeraer \& Van Petegem, 2012; Roblyer, Edwards \& Havriluk, 2004), and improves student satisfaction, attitude and learning outcomes in a positive way. It has been found to increase (Johnson \& Aragon, 2003). In this context, it is important to integrate technology and transfer abstract topics to students by concretizing them in mathematics teaching (MEB, 2019).

In this study, the two countries (Iran and Turkey) 10th grade math class field Computer Aided Mathematics Teaching students (CAMT) academic achievement of students as a result of using dmlo scope includes the quadratic equation unit, as well as attitudes and participation in the mathematics lessons from the 
experimental group between the two countries It is important to evaluate the difference between the data obtained.

In addition, it is aimed to integrate up-to-date mathematics software into education in teaching mathematics subjects to students and to increase the quality of the course taught by using information technologies. The teaching of mathematical topics, which have an abstract structure, with traditional methods by the teacher, shows that the learners cannot transfer these abstract concepts to daily life (Baki, 2015). In order to embody this abstract structure and present it to the learner in the form of a visual material, it is necessary to emphasize the importance of needing software that includes mathematical subjects, especially information technology tools.

Wolfram Mathematica is one of the most important software that can be used in mathematics curriculum. This program is preferred by many professional users because it includes the feature of continuous object updating in its infrastructure (Gülcü, 2004). When viewed from this angle; It is important to integrate the Wolfram Mathematica program into mathematics education. The integration of the Wolfram Mathematica program into education and its use in class environments contributes to the development of students' high-level thinking skills, increasing their participation in the course and supporting the permanence of learning (Ardıç \& İşleyen, 2017; Conceiçao, Pereira, Simao \& Silva, 2012; Ghosh, 2011; Taşlıbeyaz \& Gülcü, 2013; Jacobus \& Podeschi, 2018; Hereman, 1996; Rose \& Smith, 2002).

Learning objects are one of the materials that are widely used in educational environments recently and especially preferred to be used in lessons with an abstract structure such as mathematics. These objects are produced with popular software such as geogebra and Wolfram mathematica. Learning objects produced through Wolfram mathematica increase the quality of mathematics course environments and make the learning process effective. When the mathematics curriculum explained with these materials is transferred to students with concrete concepts, it leads to the development of creative thinking skills of students (Bulut, 2004; Moyer, 2001).

The participants of the study, students 56 from Shaheed Mehdi Salek High School in the city of Tabriz in Iran (28 experimental group and 28 students in the control group) and 56 students in Erzurum Province of Mehmet Akif Ersoy High School in Turkey (28 students in the experimental group and 28 students in the control group) is created.

Looking at the results of this study; Turkey 10th grade students in the experimental group as that of the average scores than the control group as compared to control group average and that positively affected their academic achievement has been to determine share. The same findings were valid for the Iranian 10th grade experimental and control groups. When we compared the scores of participation in the experimental group students in 10th grade math course Turkey was found to be a significant difference in favor of posttest. The same findings were valid for the Iranian 10th grade experimental group. Also compared in terms of attitude scores of students of mathematics courses Turkey 10th grade experimental group was found to be a significant difference in favor of posttest. The same findings were valid for the Iranian 10th grade experimental group.

Keywords: DMLO, teaching mathematics, quantitative analysis, academic success, attitude, participation in the lesson.

Öz: Bu araştırmada, Türkiye ve İran lise 10. sınıf öğrencilerinin matematiğin ikinci dereceden denklemler ünitesi için tasarlanan Dinamik Matematik Öğrenme Nesnelerinin (DMÖN'lerin); öğrencilerin akademik başarılarının, tutumlarının ve derse yönelik katılımlarının etkisinin incelenmesi amaçlanmıştır. Ayrıca Türkiye ve İran'ın eğitim şartları dikkate alınarak matematik dersinde DMÖN'lerin kullanılmasının öğrenciler üzerindeki etkisi karşılaştırılmıştır. $\mathrm{Bu}$ amaç doğrultusunda çalışmada nicel araştırma yöntemlerinde yer alan yarı deneysel deseninden faydalanılmıştır. Çalışmada verilerin toplanması için akademik başarı testi, tutum ve derse katılım ölçeği kullanılmıştır. Nicel verilerin analizinde Mann-Whitney U testi ve Wilcoxon işaretli sıralar testi uygulanmıştır. Ön test-son test deney ve kontrol gruplu yarı deneysel desen olarak dizayn edilen çalışma 112 öğrenci ile gerçekleştirilmiştir. Çalışmanın katılımcılarını İran’ın Tebriz şehrinde Şehid Mehdi Salek Lisesinden 56 öğrenci (28 deney grubu ve 28 öğrenci kontrol grubu) ve 
Türkiye'de Erzurum İlinin Mehmet Akif Ersoy Anadolu Lisesinden 56 öğrenci (28 öğrenci deney grubu ve 28 öğrenci kontrol grubu) oluşturmaktadır. 6 haftalık çalışma sonucundan elde edilen verilerin analizlerine bakıldığında; DMÖN'lerle öğrenim gören Türkiye ve İran deney grubu öğrencilerinin akademik başarı puanları, kontrol gruplarına göre daha fazla olduğu ortaya çıkmıştır. Ayrıca Türkiye ve İran deney grubu öğrencilerinin tutum ve derse katılım puanları arasında anlamlı bir fark olduğu belirtilmiştir. Her iki ülkenin (Türkiye-İran) 10. Sınıf öğrencilerinin matematik dersinde DMÖN'lerin kullanılması sonucunda, akademik başarılarının, tutumlarının ve derse katılımlarının olumlu yönde etkilendiği ortaya çıkmıştır. Bu çalışmanın verileri 2019-2020 öğretim yılına aittir.

Anahtar kelimeler: DMÖN, matematik öğretimi, nicel analiz, akademik başarı, tutum, derse katılım

\section{Giriş}

Çağımızı etkileyen hızlı gelişim ve değişim, uluslararası teknoloji ve eğitim ortamlarında da kendini göstermiş olup, nitelikli insan gücü yetiştirmeyi sağlamaktadır (MEB, 2011). Bu doğrultuda yetiştirilen öğrencilerden teknolojinin matematik gibi soyut bir derste kullanılmasının ne kadar önemli olmasının bilincinde olmaları ve günlük hayatta karşılaşılan sorunları matematiksel işlemlerle çözebilme yeteneğine sahip olmaları beklenmektedir (URL -1, 2017).

Matematik dersi soyut kavramlardan oluşan bir derstir. Bu dersin somutlaşması için klasik yöntemler dışı dinamik matematik öğrenme nesnelerinin üretilmesine gerek duyulmaktadır (Aydın \& Doğan, 2012). O yüzden bu soyut boyutun boşluğunu kapatmaya destekte bulunan bilgisayar gibi teknolojik araçların kullanılması oldukça önem taşımaktadır (İçel, 2011; Kelsey, Carl, \& Holly, 2004; Heid, 1997). Bu görüşlerden yola çıkarak matematik eğitiminde bilgisayar aracılığıyla üretilen öğrenme nesnelerinin kullanılması öğrencilerin yeni deneyimler elde ederek matematik öğrenmelerinde üstdüzey bilişsel becerilerini güçlendirmelerine imkan sağlamasına sebep olmaktadır (Baki vd., 2002).

Son yıllarda matematik eğitimi için tasarlanan öğrenme nesneleri geleneksel öğretim yöntemlerinin yerine geçerek, öğrencilerin yaparak uygulayarak öğrenmelerine yol açmaktadır. Matematik eğitiminde öğrenme nesnelerinin kullanılması, öğrencinin keşfederek ve anlayarak öğrenmesini esas almaktadır (Bulut, 2004). Ayrıca bu nesnelerle öğrencilerin matematik derslerinde aktif katılımcı olmalarının yanısıra, akranlarıyla etkileşimlerinden kendi düşüncelerini oluşturmalarına destekte bulunmaktadır. Bu yüzden soyut matematiksel ifadeleri görselleştirerek somut ve açık bir şekilde sunmak için tasarlanan öğrenme nesneleri, öğrencilerin matematik dersine yönelik tutumlarına ve derse katılımlarına etkili olmaktadır (Moyer, 2001).

$\mathrm{Bu}$ materyallerin ders ortamlarına entegre edilmesinden maksat, eğitimin kalitesini zenginleştirmek ve öğretim sürecinde öğretmenlere yardımcı bir araç olarak kullanmaktır (Karademirçi, 2010). Bunun yanısıra öğrenenlere eğlenceli bir eğitim ortamı oluşturmakla birlikte kalıcı öğrenmesine olanak sağlamaktadır (Kacar \& Doğan, 2007).

Son zamanlarda dinamik matematik öğrenme nesneleri ile ilgili yapılan çalışmalar oldukça yaygın olmaktadır. DMÖN ile ilgili çalışmaların çoğu kısmının öğrencilerde matematiğe tutumları, sınıf içi matematik derslerine yönelik katılımları ve akademik başarılarına olan etkisine bakılmaktadır. Ayrıca bilgisayar yazılımları (Geogebra, Mathematica, Sketchpad, Logo, Cabri vs.) aracılığı ile oluşturulan ve sürekli artıp yenilenen öğrenme nesneleri gibi materyallerin hazırlanması BDMÖ'nün ne kadar önemli bir öğretim metodu olduğunun göstergesidir (Selçik \& Bilgi, 2011). Yapılan araştırmalarda; öğrencilerin matematik dersinde DMÖN'leri kullandıkları zaman derse yönelik tutumlarının olumlu etkilenmesine (Aydoğdu, Erşen \& Tutak, 2014; Buteau \& Mgombelo, 2012; Gök \& Erbilgin, 2012; Kaymakç1, 2010; Salas \& Ellis, 2008; Zehir, 2010) ve akademik başarılarının artmasına yol açmışır (Karaman vd., 2006; Özerbaş \& Çiçek, 2014; Özerbaş \& K1lıç, 2017; Türel \& Gürol, 2011; Türel \& Gürol, 2009). 
Türkiye'de lise matematik dersi kapsamında 30 öğrenci ve öğretmene hazırlanan DMÖN'lerin kullanılması sonucunda; dersin eğlenceli, ilgi çekici ve etkili hale getirdiğini belirtmişlerdir (Baki \& Çakıroğlu, 2010). Benzer bir çalışmada İran'ın Elburz İlinin ilkokul 3.sınıf öğrencileri üzerinde yapılmıştır. Çalışmada uygulanan DMÖN'lerin kullanılmasının öğrencilerin akademik başarılarının artmasında, matematik dersine yönelik katılım ve tutumlarında olumlu etki yaratılmasına sebep olmuştur (Badeleh, 2017).

Başka bir çalışmada MEB tarafından 5. 6.7 ve 8. sınıflarında matematik dersi DMÖN'leri kullanması sonucunda; matematik eğitiminde kısıtlı sayıda kazanım sağlayacağını ve öğretim seviyesinin potansiyel katkılarını destekleyecek güçte olmadığını göstermiştir (Dedeoğlu, Agaç, Erdoğan \& Koçak, 2013). Bir başka çalışma İtalya'da lisans öğrencilerinin öğrenme nesnelerini kullandıkları zaman akademik başarılarının artması, tutumları, bilişsellik ve derse yönelik katılımlarının olumlu yönde etkilendiği doğrultusunda bilgiler elde edilmiştir (Fonseca vd., 2012).

İran'ın Tahran İlinin 6.sınıf öğrencileri üzerinde yapılan bir çalışmada; öğrencilerin matematik dersinde öğrenme nesnelerini kullandıktan sonra akademik başarılarının artmasına ve tutumlarının olumlu yönde etkilenmesine kanaat getirilmiştir (Zarrabian, 2018).

Alanyazında yapılan açıklamalar doğrultusunda; dinamik matematik öğrenme nesnelerinin matematiğin ikinci dereceden denklemler ünitesinde kullanılması ve Türkiye ve İran 10. sınıf öğrencilerinin üzerinde etkisinin incelenmesi araştırmacı tarafından ele alınmıştır.

\section{Araştırmanın Amacı}

$\mathrm{Bu}$ araştırmanın amacı, 10. sınıf matematik dersi II. dereceden denklemler konusunun anlatımı için hazırlanan Dinamik Matematik Öğrenme Nesnelerinin (DMÖN) kullanımının; öğrencilerin akademik başarılarına, tutumlarına ve derse katılımlarına olan etkisinin incelenmesidir. Ayrıca Türkiye ve İran'ın eğitim şartlarını dikkate alarak, 10. sınıf öğrencilerinin matematik dersinde DMÖN'lerin kullanılmasının öğrenciler üzerindeki etkisi karşılaştırılmıştır.

Araştırmada problem durumunu belirlemek için 3 araştırma sorusu düzenlenmiştir.

- DMÖN'lerin öğrencilerin akademik başarılarına etkisi açısından:

a. Deney ve kontrol grupları arasında anlamlı bir farkl1l1k var mıdır?

b. Türkiye ve İran deney grupları arasında anlamlı bir farklılık var mıdır?

- DMÖN'lerin öğrencilerin matematik dersine ilişkin tutumları açısından:

a. Deney grubu öntest-sontest puanları arasında anlamlı bir farklılık var mıdır?

b. Türkiye ve İran deney grupları arasında anlamlı bir farklılık var mıdır?

- DMÖN'lerin öğrencilerin derse katılımlarına etkisi açısından:

a. Deney grubu öntest-sontest puanları arasında anlamlı bir farklılık var mıdır?

b. Türkiye ve İran deney grupları arasında anlamlı bir farklılık var mıdır?

\section{Araştırmanın Yöntemi}

Bu çalışmada, ortaöğretim 10. sınıf öğrencileri üzerinde yürütülen uygulamadan elde edilen nicel verilerin toplanması için yarı deneysel desen kullanılmıştır (Creswell, 2008; Frankel ve Wallen, 1996). Ayrıca deney ve kontrol grupları uygun örnekleme yöntemine göre belirlenip, öntest-sontest deney ve kontrol grupları için de yarı deneysel desenden faydalanılmıştır (Creswell, 2002; Chen \& Zimmerman, 2007). Öntest-sontest karşılaştırma gruplu desen, katılımciların deneysel araştırmanın öncesinde ve sonrasında, bağımlı değişken ile ilgili ölçüme tabi tutulmasıdır (Karasar, 1999). Çalışmada İran ve Türkiye deney-kontrol grupları seçkisiz atama ile belirlenmiştir. 
$\mathrm{Bu}$ çalışmada öğrencilerin akademik başarı, derse katılım ve tutumlarını ölçmek için sırasıyla akademik başarı testi, matematik dersine yönelik tutum ölçeği ve derse katılım ölçeği kullanılmıştır. Ölçeklerden elde edilen veriler ayrı ayrı yorumlanarak sonuçta iki ülke öğrencileri arasındaki belirlenen değişkenler açısından farklılıklar ve benzerlikler üzerinde açıklamalar yapılmıştır. Ayrıca çalışmadan elde edilen veriler 2019-2020 öğretim yılına aittir.

\section{Çalışma Grubu}

Çalışma grubu, Türkiye ve İran devlet okullarında öğrenim gören 10. sınıf öğrencileri olarak belirlenmiştir. Çalışma, İran'ın Tebriz şehrinde Şehid Mehdi Salek Lisesinden seçilen toplam $56 \mathrm{k1z}$ (28 öğrenci deney grubu ve 28 öğrenci kontrol grubu) öğrenci ve Türkiye’de Erzurum İlinin Mehmet Akif Ersoy Anadolu Lisesinden seçilen 16 erkek ve 40 kız öğrenci olmak üzere toplam 56 öğrenci (28 öğrenci deney ve 28 öğrenci kontrol grubu) üzerinde yapılmıştır.

Tablo 1: Türkiye ve İran Çalışma Grubu Öğrencilerin Demografik Bilgileri

\begin{tabular}{llccc}
\hline Sinıf & Grup & Erkek & Kiz & Toplam \\
\hline $\mathbf{1 0 - C}$ & İran Deney & 0 & 28 & 28 \\
\hline $\mathbf{1 0}-\mathbf{A}$ & İran Kontrol & 0 & 28 & 28 \\
\hline $\mathbf{1 0}-\mathbf{B}$ & Türkiye Deney & 9 & 19 & 28 \\
\hline $\mathbf{1 0 - C}$ & Türkiye Kontrol & 7 & 21 & 28 \\
\hline
\end{tabular}

\section{Veri Toplama Araçları}

İran ve Türkiye'de ortaöğretim 10. sınıf öğrencilerinin matematik derslerinde DMÖN'leri kullandıkları durumlarda akademik başarılarının, matematik dersine yönelik tutum ve derse katılımlarının incelenmesinin amaçlandığı bu araştırmada nicel veri toplama aracı olarak akademik başarı testi, matematik tutum ölçeği ve derse katılım ölçeği kullanılmıştır.

\section{İkinci Dereceden Denklemler Akademik Başarı Testi}

İkinci dereceden denklemler ünitesinde akademik başarı testi hazırlanırken ilgili öğretim programında yer alan kazanımlar ve soruların bilişsel düzeylerini gösteren belirtke tablosu hazırlanmıştır. Akademik başarı testinde yer alacak soruların ortaöğretim matematik öğretimi programında yer alan kazanımları karşılayacak düzeyde olmasına dikkat edilmiştir. Bu kazanımları kapsayacak 30 soru hazırlanmıştır. Hazırlanan soruların bilimsel olarak doğru olmasını denetlemek ve güvenirliğini sağlamak için Türkiye ve İran MEB'lığına bağlı ortaöğretim dört matematik öğretmenin görüşleri dikkate alındıktan sonra teste son şekli verilmiştir.

Hazırlanmış olan çoktan seçmeli (beş seçenekli) 30 soruluk testte, öğrencilerin II. dereceden denklemler ünitesinde kazanımlarına uygun şekilde analiz, kavram oluşturma ve değerlendirme yapabilmeleri için gereken soruların yer almasına önem verilmiştir. Hazırlanan akademik başarı testi soruları, Türkiye ve İran'da aynı konuyu öğrenmiş olan 12. sınıf (İran'da 60 öğrenci-Türkiye'de 50 öğrenci) toplam 110 öğrenciye uygulanmıştır. Uygulamadan elde edilen veriler excel programında analiz edilmiştir. Ortaya çıkan analiz sonuçlarında, KR-20 güvenirlik katsayısı 0.79 olarak bulunmuştur. Soruların madde ayırt edicilik indeksinde 5 sorunun ayırt edicilik indeksi 0.30 'un altında olduğu için akademik başarı testinden çıkarılmıştır. Böylelikle testteki soru sayısı 25 olarak belirlenmiştir. Akademik başarı testinden 5 sorunun çıkartılması sonucu kalan 25 sorunun KR-20 güvenirlik katsayısı hesaplanmış ve 0.81 olarak bulunmuştur. Tablo 2'de hazırlanmış akademik başarı testinin güçlük $\left(\mathbf{P}_{\mathbf{g x}}\right)$ ve ayırt edicilik $\left(\mathbf{R}_{\mathbf{g x}}\right)$ indeksleri verilmiştir. 
Tablo 2: Akademik Başarı Soruların Madde Güçlük ve Ayırt Edicilik İndeksleri

\begin{tabular}{cccccccc}
\hline Soru & $\mathbf{P}_{\mathbf{g x}}$ & $\mathbf{R}_{\mathbf{g x}}$ & Açıklama & Soru & $\mathbf{P}_{\mathbf{g x}}$ & $\mathbf{R}_{\mathbf{g x}}$ & Açıklama \\
\hline S1 & 0.71 & 0.43 & Kolay bir madde & $\mathrm{S} 14$ & 0.70 & 0.41 & Kolay bir madde \\
S2 & 0.65 & 0.37 & Kolay bir madde & $\mathrm{S} 15$ & 0.62 & 0.79 & Kolay bir madde \\
S3 & 0.78 & 0.47 & Kolay bir madde & $\mathrm{S} 16$ & 0.37 & 0.63 & Zor bir madde \\
S4 & 0.71 & 0.38 & Kolay bir madde & $\mathrm{S} 17$ & 0.34 & 0.67 & Zor bir madde \\
S5 & 0.68 & 0.51 & Kolay bir madde & $\mathrm{S} 18$ & 0.40 & 0.71 & Zor bir madde \\
S6 & 0.83 & 0.42 & Çok kolay bir madde & $\mathrm{S} 19$ & 0.50 & 0.91 & Zor ve ayırt edici bir madde \\
S7 & 0.70 & 0.34 & Kolay bir madde & $\mathrm{S} 20$ & 0.48 & 0.76 & Zor ve ayırt edici bir madde \\
S8 & 0.66 & 0.56 & Kolay bir madde & $\mathrm{S} 21$ & 0.55 & 0.38 & Zor ve ayırt edici bir madde \\
S9 & 0.38 & 0.66 & Zor bir madde & $\mathrm{S} 22$ & 0.61 & 0.79 & Kolay bir madde \\
S10 & 0.73 & 0.52 & Kolay bir madde & $\mathrm{S} 23$ & 0.42 & 0.81 & Zor ve ayırt edici bir madde \\
S11 & 0.65 & 0.68 & Kolay bir madde & $\mathrm{S} 24$ & 0.42 & 0.54 & Zor ve ayırt edici bir madde \\
S12 & 0.74 & 0.41 & Kolay bir madde & $\mathrm{S} 25$ & 0.58 & 0.86 & Zor ve ayırt edici bir madde \\
S13 & 0.68 & 0.62 & Kolay bir madde & $\ldots \ldots$ & $\ldots \ldots$ & $\ldots \ldots$ & $\ldots \ldots \ldots \ldots \ldots \ldots . . .$. \\
\hline
\end{tabular}

\section{Matematik Tutum Ölçeği}

$\mathrm{Bu}$ çalışmada Aşkar (1986) tarafından geliştirilen ve 20 maddeden oluşan tutum ölçeği öğrenciler üzerinde uygulanmıştır. Matematik dersine yönelik tutum ölçeğinin her maddesi 5 'er seçenekten oluşmaktadır. Seçenekler sirayla "Tamamen Uygundur=5", "Uygundur=4", "Kararsızım=3", "Uygun Değildir=2", "Hiç Uygun Değildir=1" maddelerinden oluşmaktadır. Ölçekte maddelerinin değer anlamları yarı yarıya olumlu ve olumsuz şeklinde hazırlanmıştır. Ölçeğin Fars diline çevirisi Türkçe ve Fars dilinde eğitim almış bir uzman tarafından yapılmıştır. Fars dilinde yapı geçerliğinin sağlanması için 213 öğrenciden veri toplanmıştır. Toplanılan verilerden eksik ve hatalı doldurulanlar atıldıktan sonra kalan 202 veri ile Doğrulayıcı faktör analizi uygulanmıştır. Yapı geçerliğinden elde edilen analiz sonuçları Tablo 3'te sunulmuştur.

Tablo 1: Matematik Dersine Tutum Ölçeği Uyum Değerleri

\begin{tabular}{cccc}
\hline Uyum Ölçüleri & İyi Uyum Değerleri & $\begin{array}{c}\text { Kabul Edilebilir Uyum } \\
\text { Değerleri }\end{array}$ & $\begin{array}{c}\text { Ölçeğe İlişkin } \\
\text { Uyum Değerleri }\end{array}$ \\
\hline$x 2 / \mathrm{df}$ & $00<x 2 / \mathrm{df}<2$ & $2<x 2 / \mathrm{df}<3$ & 2.10 \\
GFI & $0.95<\mathrm{GFI}<1.00$ & $0.80<\mathrm{GFI}<0.95$ & 0,82 \\
AGFI & $0.90<\mathrm{AGFI}<1.00$ & $0.80<\mathrm{AGFI}<0.90$ & 0,83 \\
CFI & $0.95<\mathrm{CFI}<1.00$ & $0.90<\mathrm{CFI}<0.95$ & 0,89 \\
IFI & $0.95<\mathrm{IFI}<1.00$ & $0.90<\mathrm{IFI}<0.95$ & 0,91 \\
SRMR & $0.00<$ SRMR $<0.05$ & $0.05<$ SRMR $<0.10$ & 0,08 \\
RMSEA & $0.00<$ RMSEA $<0.05$ & $0.05<\mathrm{RMSEA}<0.080$ & 0,06 \\
\hline
\end{tabular}

Eşik değerler bağlamında literatüre göre GFI (Doll, Xia, \& Torkzadeh, 1994, ss. 458) ve AGFI (Segars \& Grover, 1993, ss. 522) değerleri için 0,80-0,89 arası değerlerde kabul edilebilir. Tablo 3 incelendiğinde matematik dersine yönelik tutum ölçeğinin uyum CFI değeri eşik değere çok yakın bulunduğu ortaya çıkmıştır. Bu bulgulara göre Matematik dersine yönelik tutum ölçeği bu haliyle lise öğrencilerinin matematik dersine yönelik tutumlarını ölçebilmesi açısından yapı geçerliğini sağlamıştır. Yapı geçerliği sonrasında yapılan Cronbach Alfa güvenirlik testi yapılmıştır. Olumsuz maddelerin analizinden elde edilen verileri ters çevirerek üzerinde analiz ve 
değerlendirme yapılmıştır. Sonuç olarak matematik tutum ölçeğinin güvenirlik katsayısı Cronbach's $\alpha$ değeri 0.89 bulunmuştur.

\section{Matematik Dersine Katılım Ölçeği}

Çalışmada kullanılan katılım ölçeği, Reeve ve Tseng (2011) tarafından tasarlanmış ve Hıdıroğlu (2014) tarafından Türkçe'ye uyarlanmıştır. Bu ölçekte öğrencilerin matematik dersine yönelik katılımlarının ne seviyede olduğunu ölçmek için 20 maddeden ve her madde için 5'er seçenekli "Kesinlikle Katılmıyorum=5", "Katılmıyorum=4", "Kararsızım=3", "Katılıyorum=2", "Kesinlikle Katılıyorum=1" sorular kullanılmıştır. Ölçeğin Fars diline çevirisi Türkçe ve Fars dilinde eğitim almış bir uzman tarafından yapılmıştır. Fars dilinde yapı geçerliğinin sağlanması için 215 öğrenciden veri toplanmıştır. Toplanan verilerden eksik ve hatalı doldurulanlar çıkarıldıktan sonra kalan 205 veri ile Doğrulayıcı faktör analizi uygulanmıştır. Yapı geçerliğinden elde edilen analiz sonuçları Tablo 4'te sunulmuştur.

Tablo 4: Matematik Dersine Katılım Ölçeği Uyum Değerleri

\begin{tabular}{cccc}
\hline Uyum Ölçüleri & İyi Uyum Değerleri & Kabul Edilebilir Uyum Değerleri & $\begin{array}{c}\text { Ölçeğe İlişkin } \\
\text { Uyum Değerleri }\end{array}$ \\
\hline x $2 / \mathrm{df}$ & $00<x 2 / \mathrm{df}<2$ & $2<x 2 / \mathrm{df}<3$ & 1.90 \\
GFI & $0.95<\mathrm{GFI}<1.00$ & $0.80<\mathrm{GFI}<0.95$ & 0,82 \\
AGFI & $0.90<\mathrm{AGFI}<1.00$ & $0.80<\mathrm{AGFI}<0.90$ & 0,85 \\
CFI & $0.95<\mathrm{CFI}<1.00$ & $0.90<\mathrm{CFI}<0.95$ & 0,91 \\
IFI & $0.95<\mathrm{IFI}<1.00$ & $0.90<\mathrm{IFI}<0.95$ & 0,90 \\
SRMR & $0.00<\mathrm{SRMR}<0.05$ & $0.05<\mathrm{SRMR}<0.10$ & 0,06 \\
RMSEA & $0.00<\mathrm{RMSEA}<0.05$ & $0.05<\mathrm{RMSEA}<0.080$ & 0,05 \\
\hline
\end{tabular}

Eşik değerler bağlamında literatüre göre GFI (Doll vd., 1994, ss. 458) ve AGFI (Segars \& Grover, 1993, ss. 522) değerleri için 0,80-0,89 arası değerlerde kabul edilebilir. Tablo 4 incelendiğinde matematik dersine yönelik katılım ölçeğinin uyum CFI değerinin eşik değere çok yakın bulunduğu ortaya çıkmıştır. Bu bulgulara göre Matematik dersine katılım ölçeği bu haliyle lise öğrencilerinin, matematik dersine katılımlarını ölçebilmesi açısından yapı geçerliğini sağlamıştır. Matematik dersine katılım ölçeğinin güvenirlik katsayısı Cronbach's $\alpha$ değeri 0.85 bulunmuştur.

\section{Verilerin Analizi}

Araştırmada toplanan veriler için nicel veri analiz yöntemi kullanılmıştır. Verilerin analizi için SPSS26 programı kullanılmıştır. Nicel verilerin toplanması için öncelikle Türkiye-İran deney grubu üzerinde uygulanan öntest akademik başarı, tutum ve derse katılım puanlarından elde edilen verilerin normalliği ve homojenliği kontrol edilmiştir. Verilerin normalliği sağlanmadığı için, analizlerde Mann whitney-U ve Wilcoxson işaretli sıralar testlerinin birlikte kullanılmasına karar verilmiştir.

\section{Araştırmanın Gruplar Arası Denkliği}

Deneysel çalışmaların en önemli aşamalarından birisi de çalışma gruplarının (deneykontrol) değişkenler açısından birbiri ile denk olmasıdır. Grupların denkliğini kontrol etmek için öğrencilerin birinci dönem matematik karne notları ve öntest olarak uygulanmış II. dereceden denklemler ünitesi akademik başarı testi puanlarına bakılmıştır. Öğrencilerin karne notları ve öntest akademik başarı puanlarının normallik şartı sağlanmadığı için Mann Whitney-U testi kullanılmıştır. Yapılan çalışmanın istatistiksel analizi ve sonuçları aşağıdaki tablolarda detaylı olarak açıklanmıştır. 
Tablo 5: Türkiye 10. Sınıf Deney ve Kontrol Grubu Öğrencilerinin Matematik Dersi Karne Notları Açısından Denklik Durumu(whitney-U Testi)

\begin{tabular}{cccccccc}
\hline Gruplar & $\mathrm{n}$ & $\begin{array}{c}\text { Sira } \\
\text { Ortalamas1 }\end{array}$ & Sira Toplamı & $\overline{\mathrm{x}}$ & ss & $\mathrm{U}$ & $\mathrm{p}$ \\
\hline Deney Grubu & 28 & 28.89 & 809.00 & 70.36 & 14.26 & 381.00 & 0.85 \\
Kontrol Grubu & 28 & 28.11 & 787.00 & 69.64 & 12.01 & & \\
\hline
\end{tabular}

Tablo 5'e bakıldığında; Mann whitney-U testi sonuçlarına göre, Türkiye deney grubu öğrencilerinin matematik dersinden aldıkları karne notu puanı sira ortalaması $\mathrm{SO}_{\mathrm{D}}=28.89$ ve ortalamayla standart sapmas1 $\bar{x}=70.36$ ve $S S=14.26$ iken, kontrol grubu öğrencilerinin matematik dersinden aldıkları karne notu puanı sira ortalamas $1 \mathrm{SO}_{\mathrm{K}}=28.11$ ve ortalamayla standart sapmas1 $\overline{\mathrm{x}}=69.64$ ve $\mathrm{SS}=12.01$ olmuştur. Sıra ortalamaları arası farklılığın anlamlı olup olmadığına bakıldığında; $U=381 ; p>0.05$ olduğu için, deney ve kontrol grubu öğrencilerinin matematik dersi karne notu puanları açısından aralarında anlamlı bir fark olmadığı ve grupların denk olduğu gösterilmiştir.

Tablo 6: İran 10. Sınıf Deney ve Kontrol Grubu Öğrencilerinin Matematik Dersi Karne Notları Açısından Denklik Durumu(Mann whitney-U Testi)

\begin{tabular}{cccccccc}
\hline Gruplar & $\mathrm{n}$ & $\begin{array}{c}\text { Sira } \\
\text { Ortalamas1 }\end{array}$ & Sira Toplamı & $\overline{\mathrm{x}}$ & ss & $\mathrm{U}$ & $\mathrm{p}$ \\
\hline Deney Grubu & 28 & 29.21 & 818.00 & 71.79 & 12.48 & 372.00 & 0.73 \\
Kontrol Grubu & 28 & 27.79 & 778.00 & 71.07 & 10.65 & & \\
\hline
\end{tabular}

Tablo 6'ya bakıldığında; Mann Whitney-U testi sonuçlarına göre, İran deney grubu öğrencilerinin matematik dersinden aldıkları karne notu puanı sira ortalaması $S_{D}=29.21$ ve ortalamayla standart sapmas1 $\overline{\mathrm{x}}=71.79$ ve $\mathrm{SS}=12.48 \mathrm{iken}$, kontrol grubu öğrencilerinin matematik dersinden aldıkları karne notu puanı sira ortalamas $1 \mathrm{SO}_{\mathrm{K}}=27.79$ ve ortalamayla standart sapmas1 $\overline{\mathrm{x}}=71.07$ ve $\mathrm{SS}=10.65$ olmuştur. Sıra ortalamaları arası farklılığın anlamlı olup olmadığına bakıldığında; $U=372 ; p>0.05$ olduğu için, deney ve kontrol grubu öğrencilerinin matematik dersi karne notu puanları açısından aralarında anlamlı bir fark olmadığı ve grupların denk olduğu gösterilmiştir.

Çalışmada; Türkiye-İran 10. sınıf deney ve kontrol grubu öğrencilerine matematiğin II. dereceden denklemler ünitesi bazında uygulanan akademik başarı öntest puanları açısından denkliği aşağıdaki statistiksel analizlerde verilmiştir.

Tablo 7: Türkiye 10. Sınıf Deney ve Kontrol Grubu Öğrencilerinin Akademik Başarı Öntest Puanları Açısından Denklik Durumu(Mann Whitney-U Testi)

\begin{tabular}{cccccccc}
\hline Gruplar & $\mathrm{n}$ & $\begin{array}{c}\text { Sira } \\
\text { Ortalamas1 }\end{array}$ & Sira Toplamı & $\overline{\mathrm{x}}$ & $\mathrm{ss}$ & $\mathrm{U}$ & $\mathrm{p}$ \\
\hline Deney Grubu & 28 & 30.14 & 844.00 & 29.71 & 6.92 & 346.00 & \multirow{2}{*}{0.44} \\
Kontrol Grubu & 28 & 26.86 & 752.00 & 28.43 & 12.28 & & \\
\hline
\end{tabular}

Tablo 7'ye bakıldığında; MannWhitney-U testi sonuçlarına göre, Türkiye deney grubu öğrencilerinin matematik dersinden aldıkları akademik başarı puanı sıra ortalaması $\mathrm{SO}_{\mathrm{D}}=30.14$ ve ortalamayla standart sapmasi $\overline{\mathrm{x}}=29.71$ ve $\mathrm{SS}=6.92$ iken, kontrol grubu öğrencilerin matematik dersinden aldıkları akademik başarı puanı sıra ortalaması $\mathrm{SO}_{\mathrm{K}}=26.86$ ve ortalamayla standart sapmas1 $\overline{\mathrm{x}}=28.43$ ve $\mathrm{SS}=12.28$ olmuştur. Sira ortalamaları aras 1 farklılığın anlamlı olup olmadığına bakıldığında; $U=346 ; p>0.05$ olduğu için, deney ve kontrol grubu öğrencilerinin matematik dersi 
akademik başarı puanları açısından aralarında anlamlı bir fark olmadığı ve grupların denk olduğu gösterilmiştir.

Tablo 8: İran 10. Sınıf Deney ve Kontrol Grubu Öğrencilerinin Matematik Dersi Akademik Başarı Öntest Puanları Açısından Denklik Durumu(MannWhitney-U Testi)

\begin{tabular}{cccccccc}
\hline Gruplar & $\mathrm{n}$ & $\begin{array}{c}\text { Sira } \\
\text { Ortalamas1 }\end{array}$ & Sira Toplamı & $\overline{\mathrm{x}}$ & ss & $\mathrm{U}$ & $\mathrm{p}$ \\
\hline Deney Grubu & 28 & 28.84 & 807.50 & 31.14 & 8.17 & 382.50 & 0.87 \\
Kontrol Grubu & 28 & 28.16 & 788.50 & 29.86 & 4.68 & & \\
\hline
\end{tabular}

Tablo 8'e bakıldığında; Mann Whitney-U testi sonuçlarına göre, İran deney grubu öğrencilerinin matematik dersinden aldıkları öntest akademik başarı puanı sıra ortalaması $\mathrm{SO}_{\mathrm{D}}=28.84$ ve ortalamayla standart sapmas1 $\overline{\mathrm{x}}=31.14$ ve $\mathrm{SS}=8.17 \mathrm{iken}$, kontrol grubu öğrencilerinin matematik dersinden aldıkları öntest akademik başarı puanı sıra ortalaması $\mathrm{SO}_{\mathrm{K}}=28.16$ ve ortalamayla standart sapmas1 $\overline{\mathrm{x}}=29.86$ ve $\mathrm{SS}=4.68$ olmuştur. Sıra ortalamaları aras1 farkl11ığın anlamlı olup olmadığına bakıldığında; $\mathrm{U}=382.50 ; \mathrm{p}>0.05$ olduğu için, deney ve kontrol grubu ögrencilerinin matematik dersi akademik başarı puanları açısından aralarında anlamlı bir fark olmadığı ve grupların denk olduğu gösterilmiştir.

\section{Araştırmacının Rolü}

$\mathrm{Bu}$ çalı̧̧mada araştırmacı uygulama sürecinde bir öğretici pozisyonundadır. Uygulama esnasında ortaya çıkan sorunların giderilmesinde katılımcılara yardımda bulunup sonraki haftalarda yapılacak işlemlerde benzeri sorunların yaşanmaması için gerekli önlemleri almıştır. Ölçeklerin Fars diline çevrilmesi araştırmacı tarafından yapılmıştır. Ayrıca araştırmacı uygulama sürecine başlamadan önce öğretmen ve öğrencilere Wolfram Mathematica yazılımı ile hazırlanmış DMÖN'lerin nasıl kullanılması hakkında gereken bilgilendirmeleri yapmıştır.

\section{Geçerlik ve Güvenirlik}

$\mathrm{Bu}$ araştırmada nicel yöntemin kullanılması sonucunda; nicel yöntemin geçerliği ve gücvenirliği için sonuçların hatasız olmasını ve böylece güvenirliğini sağlamak için de sonuçların genelleme yapabilme özelliğine önem verilmiştir. Geçerlik önlemleri için örneklem türü seçimine, katılımcıların bireysel, kültürel ve ekonomik özelliklerine ve veri toplama araçlarının detaylı bir şekilde açıklanmasına önem verilmiştir. Güvenirlik önlemleri için sınıf ortamında öğrencilerin fotoğraflarının çekilmesine, esas uygulamaya başlamadan önce pilot uygulama yapılmasına ve ölçeklerin güvenirlik hesaplamalarının ele alınmasına özen gösterilmiştir.

\section{Uygulama Süreci}

Araştırmanın pilot ve esas uygulaması, İran'ın Tebriz il merkezinde şehid Mehdi Salek Lisesinde öğrenim gören 56 öğrenci üzerinde yürütülmüştür. Aynı süreç Erzurum Mehmet Akif Ersoy Anadolu Lisesinde 56 öğrenci üzerinde uygulanmıştır. Uygulamalar her iki okul için sınıf içinde ve her öğrenciye bir adet diz üstü bilgisayar verilerek yapılmıştır. Araştırmacı tarafından altı haftalık uygulama sürecinde wolfram mathematica aracılığyla hazırlanan 15 adet DMÖN'ler hakkında öğrenciler ve öğretmenlere gereken bilgilendirmeler yapılmıştır. Uygulama sürecinde öğrencilerin yapılandırmacı öğrenmelerine, sınıf içi işbirlikli çalışmalarına ve eğitim performanslarının artmasına dikkat ederek DMÖN'ler geliştirilmiştir.

İki ülkenin ortaöğretim matematik müfredatı içeriğinin yakın olduğu için, uygulama ilk başta 2019-2020 eğitim-öğretim yılı birinci döneminde İran'ın Tebriz İlinin Şehid Mehdi Salek Lise öğrencileri üzerinde uygulanmıştır. 2019-2020 eğitim-öğretim yılı ikinci döneminde Türkiye'de Erzurum ilinde Mehmet Akif Ersoy Anadolu Lisesinde uygulanmıştır. Ayrıca İran ve Türkiye'de 2018 yılında yayınlanan lise matematik öğretimi programı kapsamında, 10. sınıf 
matematik dersi "II. dereceden denklemler" konusu üzerinde bilgisayar destekli etkinliklere dayalı uygulamalar yapılmıştır. "II. dereceden denklemler" konusuyla ilgili hazırlanmış nesnelerde Türkçe-Farsça konu anlatımları Wolfram Mathematica ile görselleştirilmiştir. Bu nesneler bilgisayar ortamından Wolfram Player programı aracılı̆̆ıyla öğrencilere sunulmuştur. Öğrencilerin bilgisayar laboratuvarında ya da kişisel bilgisayarlarında Wolfram Mathematica programı ile hazırlanan DMÖN'leri bilgisayarlarında kullanarak "II. dereceden denklemler" konusunu ders ortamında ders içerisinde ve ders saatleri dışında öğrenmeleri planlanmıştır.

Birinci haftada öğrencilerin II. dereceden denklemler ünitesini anlamasında dikkatlerinin artmasını sağlamak için üç adet öğrenme nesnesi geliştirilmiştir ve öğrenciler bu nesneleri kullanmaya başlamışlar. Bu üç nesne kullanılarak, öğrencilere II. dereceden bir bilinmeyenli denklemin anlamı öğretilmeye çalışılmıştır. Şekil 1'de uygulamaya katılan bir öğrenciye ait görsel ve DMÖN örneği sunulmuştur.
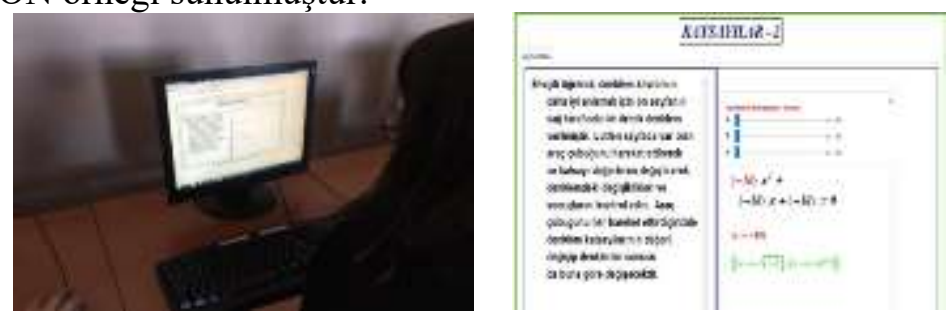

Şekil 11:Mehmet Akif Ersoy Anadolu Lisesi grup çalışması ve DMÖN örneği

İkinci haftada II. dereceden bir bilinmeyenli denklemin çözümü ile ilgili üç adet öğrenme nesnesi geliştirilmiştir. Bu nesnelerde öğrencilere II. dereceden bir bilinmeyenli denklemin çözümü ile ilgili farklı örnekler sunulması ile birlikte, değişik çözüm yöntemlerin kullanılmasına imkân sağlanmıştır. Şekil 2'de uygulamaya katılan bir öğrenciye ait görsel ve DMÖN örneği sunulmuştur.
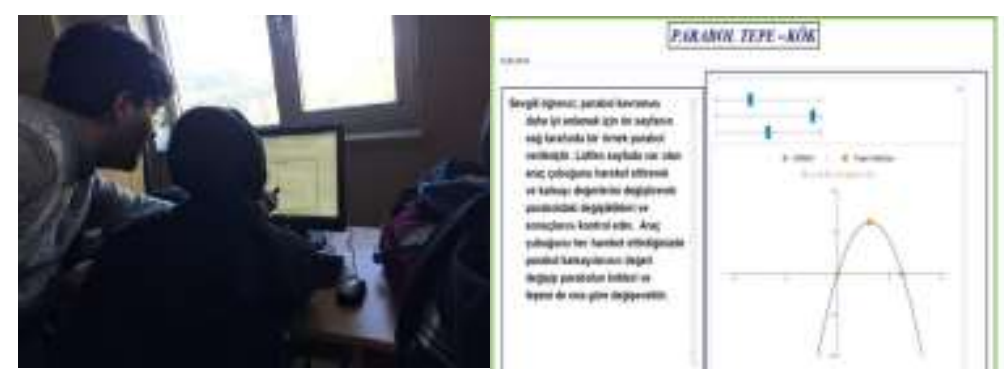

Şekil 22: Mehmet Akif Ersoy Anadolu Lisesi grup çalışması ve DMÖN örneği

Üçüncü haftada II. dereceden bir bilinmeyenli denklemin köklerinin bulunmasıyla ilgili 3'er adet öğrenme nesnesi geliştirilmiştir. Hazırlanan nesnelerin içeriğinde, öğrencilerin konu hakkında açıklama ve yorum yapabilmeleri amaçlanmıştır. Şekil 3'te uygulamaya katılan bir öğrenciye ait görsel ve DMÖN örneği sunulmuştur.
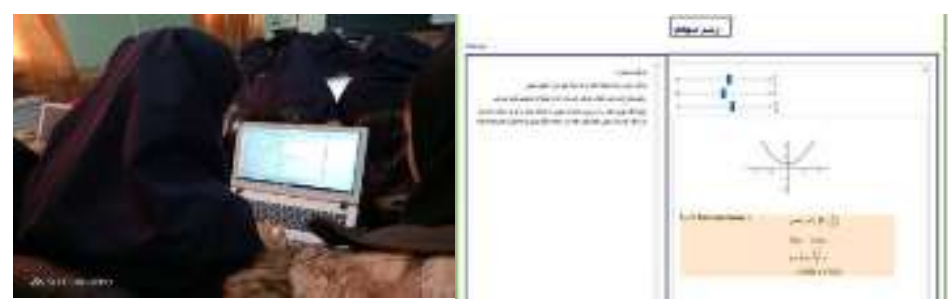

Şekil 33: Şehid Mehdi Salek Lisesi grup çalışması ve DMÖN örneği

Dördüncü ve beşinci haftalarda öğrencilere iki adet öğrenme nesnesi geliştirilmiştir. Bu nesnelerle II. dereceden bir bilinmeyenli denklemin kökleri ve köklerle katsayılar arasındaki ilişki 
açıklanmaya çalışılmıştır. Şekil 4'te uygulamaya katılan bir öğrenciye ait görsel ve DMÖN örneği sunulmuştur.

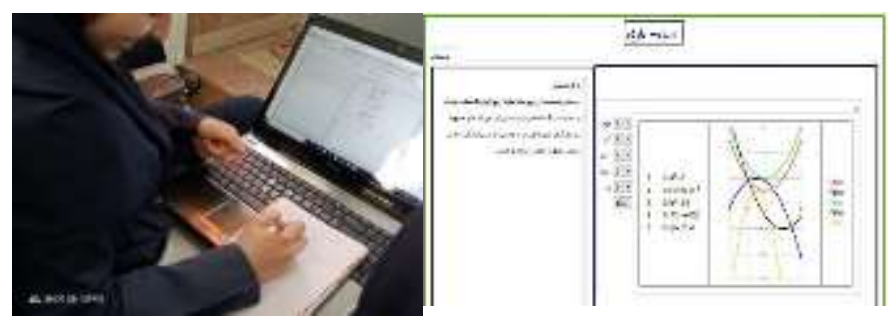

Şekil 44: Şehid Mehdi Salek Lisesi grup çalışması ve DMÖN örneği

Altıncı haftada öğrencilere II. dereceden bir bilinmeyenli denklemin grafiklerinin çizilmesiyle ilgili nesneler hazırlanmıştır. Uygulama sonunda öğrenciler köklerle denklemin grafikleri arasında ilişkiyi anlamaya ve değerlendirme yapmaya çalışmışlardır. Şekil 5'te uygulamaya katılan bir öğrenciye ait görsel ve DMÖN örneği sunulmuştur.

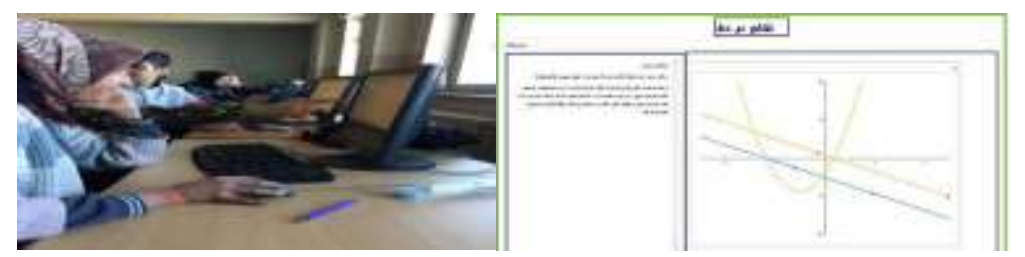

Şekil 55: Mehmet Akif Ersoy Anadolu Lisesi grup çalışması ve DMÖN örneği

Uygulama sürecinde öğrencilerin yapılandırmacı öğrenmelerine, sınıfiçi işbirlikli çalışmalarına ve eğitim performanslarının artmasına dikkat ederek DMÖN'ler geliştirilmiştir.

\section{Bulgular ve Yorumlar}

Çalışmanın bu bölümünde araştırma sorularına ait analizlerden ortaya çıkan bulgulara yer verilmiştir. Her bir araştırma sorusuna yönelik bulgular ve yorumlar başlıklar altında sunulmuştur.

\section{DMÖN Uygulamalarının Akademik Başarıya Etkisi}

Bu bölümde; Türkiye ve İran deney ve kontrol gruplarının sontest akademik başarı puanları açısından istatistiksel olarak anlamlı fark olup olmadığını tepit etmek için Mann Whitney-U testi kullanılmıştır. Tablo 9'da Mann Whithney-U testi ile deney ve kontrol gruplarının sontest akademik başarı puanlarına göre yapılan analiz sonuçları verilmiştir.

Tablo 9: Türkiye 10. Sınıf Deney ve Kontrol Grubu Öğrencilerinin Sontest Akademik Başarı Puanlarına İlişkin Mann Whitney-U Sonuçları

\begin{tabular}{cccccc}
\hline Gruplar & $\mathrm{n}$ & Sira Ortalamas1 & Sira Toplamı & $\mathrm{U}$ & $\mathrm{p}$ \\
\hline Deney Grubu & 28 & 38.14 & 1068.00 & & \\
Kontrol Grubu & 28 & 18.86 & 528.00 & & 0.001 \\
\hline
\end{tabular}

Tablo 9'daki Mann Whitney-U testi sonuçlarına göre, Türkiye deney grubu öğrencilerinin matematik dersinden aldıkları sontest akademik başarı puanı sıra ortalamas $\mathrm{SO}_{\mathrm{D}}=38.14$ iken, kontrol grubu öğrencilerinin matematik dersinden aldıkları sontest akademik başarı puanı sıra ortalaması $\mathrm{SO}_{\mathrm{K}}=18.86$ olarak bulunmuştur. Sıra ortalamaları arası farklılığın anlamlı olup olmadığına bakıldığında $\mathrm{U}=122 ; \mathrm{p}<0.05$, deney ve kontrol grubu öğrencilerinin matematik dersi sontest akademik başarı puanı açısından deney grubu lehine anlamlı bir fark olduğu ortaya çıkmıştır. $\mathrm{Bu}$ bulguya göre DMÖN'lerin II. dereceden denklemler ünitesinde öğrencilerin 
akademik başarılarını anlamlı düzeyde artırdığı söylenebilir. Tablo 10'da İran deney ve kontrol grubu öğrencilerinin sontest akademik başarı puanlarına ilişkin analizler sunulmuştur.

Tablo 2: İran 10. Sınıf Deney ve Kontrol Grubu Öğrencilerinin Sontest Akademik Başarı Puanlarına İlişkin Mann Whitney-U Sonuçları

\begin{tabular}{cccccc}
\hline Gruplar & $\mathrm{n}$ & Sira Ortalamas1 & Sira Toplamı & $\mathrm{U}$ & $\mathrm{p}$ \\
\hline Deney Grubu & 28 & 38.54 & 1079.00 & \multirow{2}{*}{111.00} & \multirow{2}{*}{0.000} \\
Kontrol Grubu & 28 & 18.46 & 517.00 & & \\
\hline
\end{tabular}

Tablo 10'daki Mann Whitney-U testi sonuçlarına göre, İran deney grubu öğrencilerinin matematik dersinden aldıkları sontest akademik başarı puanı sıra ortalaması $\mathrm{SO}_{\mathrm{D}}=38.54$ iken, kontrol grubu öğrencilerinin matematik dersinden aldıkları sontest akademik başarı puanı sıra ortalaması $\mathrm{SO}_{\mathrm{K}}=18.46$ olarak bulunmuştur. Sira ortalamaları arası farklılı̆̆ın anlamlı olup olmadığına bakıldığında $\mathrm{U}=111 ; \mathrm{p}<0.05$, deney ve kontrol grupları öğrencilerinin matematik dersi sontest akademik başarı puanı açısından deney grubu lehine anlamlı bir fark olduğu ortaya çıkmıştır. Bu bulguya göre DMÖN'lerin II. dereceden denklemler ünitesinde öğrencilerin akademik başarılarını anlamlı düzeyde artırdığı söylenebilir.

\section{Türkiye-İran Deney Gruplarının Akademik Başarı Puanları Arasındaki Farklılık}

$\mathrm{Bu}$ başlık altında; Mann Whitney-U testi sonuçlarına göre, Türkiye ve İran deney gruplarının öntest akademik başarı puanları arasında anlamlı bir farklılık olmadığı için, iki ülkenin deney gruplarının sontest akademik başarı puanları üzerinden anlamlılığı analiz edilmiştir. Tablo 11 'de Türkiye ve İran deney grubu öğrencilerinin sontest puanlarına dair analizler sunulmuştur.

Tablo 11: Türkiye-İran 10. Sınıf Deney Grubu Öğrencilerinin Sontest Akademik Başarı Puanlarına İlişkin Mann Whitney-U Sonuçları

\begin{tabular}{cccccc}
\hline Gruplar & $\mathrm{n}$ & Sira Ortalaması & Sira Toplamı & $\mathrm{U}$ & $\mathrm{p}$ \\
\hline Tr Deney Grubu & 28 & 36.50 & 1022.00 & & \\
İr Deney Grubu & 28 & 20.50 & 574.00 & 168.00 & 0.0002 \\
\hline
\end{tabular}

Tablo 11'deki Mann Whitney-U testi sonuçlarına göre, Türkiye deney grubu öğrencilerinin matematik dersinden aldıkları sontest akademik başarı puanı sıra ortalaması $\mathrm{SO}_{\mathrm{D}}=36.50$ iken, İran deney grubu öğrencilerinin matematik dersinden aldıkları sontest akademik başarı puanı sıra ortalamas $\mathrm{SO}_{\mathrm{K}}=20.50$ olarak bulunmuştur. Sira ortalamaları arası farklılı̆̆ın anlamlı olup olmadığına bakıldığında $U=168 ; p<0.05$, Türkiye ve İran deney grubu öğrencilerinin matematik dersi sontest akademik başarı puanı açısından Türkiye deney grubu lehine anlamlı bir fark olduğu ortaya çıkmıştır. Bu bulguya göre DMÖN'lerin II. dereceden denklemler ünitesinde Türkiye deney grubu öğrencilerinin akademik başarılarını anlamlı düzeyde artırdığı söylenebilir.

\section{DMÖN Uygulamalarının Tutuma Etkisi}

Bu bölümde; Türkiye ve İran deney gruplarının öntest-sontest sıra ortalaması puanları arasındaki değişimin anlamlı olup olmadığını tespit etmek için Wilcoxon işaretli sıralar testi kullanılmıştır. Tablo 12'de Wilcoxon işaretli sıralar testi ile Türkiye deney grubuna dair öntestsontest tutum puanlarını gösteren tablo sunulmuştur. 
Tablo 3: Türkiye 10. Sınıf Deney Grubu Öğrencilerinin Tutum Ölçeği Puanlarına İlişkin Wilcoxon Testi

\begin{tabular}{ccccccc}
\hline Puan & Siralar & $\mathrm{n}$ & S.O & S.T & Z & $\mathrm{p}$ \\
\hline \multirow{2}{*}{ Tr Deney Grubu Tutum } & Negatif Siralar & 7 & 11.64 & 81.50 & -2.390 & 0.017 \\
& Pozitif Siralar & 19 & 14.18 & 269.50 & & \\
Sontest- Öntest & Eşit & 2 & & & & \\
& Toplam & 28 & & & & \\
\hline
\end{tabular}

Tablo 12'deki Wilcoxon testi sonuçlarına göre, Türkiye deney grubunda öntest tutum puanına göre sontest tutum puanını düşüren öğrenci sayısı, sıra ortalaması puanları $\mathrm{N}=7$, $\mathrm{S} . \mathrm{O}=11.64$ iken, öntest tutum puanına göre sontest tutum puanını artıran öğrenci sayısı, sıra ortalaması puanları $\mathrm{N}=19, \mathrm{~S} . \mathrm{O}=14.18$ olarak ortaya çıkmıştır. Öntest-sontest puanları değişmeyen öğrenci sayısı ise iki öğrenci olarak $\mathrm{N}=2$ bulunmuștur. $\mathrm{Bu}$ bağlamda, Türkiye deney grubu öğrencilerinin matematik tutum puanlarının sira ortalamaları arası farklılığın anlamlı olup olmadığına bakıldığında; $\mathrm{Z}=-2.390 ; \mathrm{p}<0.05$, deney grubu öğrencileri matematik dersi tutum puanları açısından karşılaştırıldığında sontest lehine anlamlı bir farklılık olduğu görülmüştür. Tablo 12'deki pozitif ve negatif sıra ortalamalarına bakıldığında; Türkiye 10. sınıf deney grubu öğrencilerinin pozitif sıra ortalama puanı negatif sıra ortalama puanından fazla olduğundan hareketle, deney grubu öğrencilerinin matematik dersinde DMÖN'leri kullandıkları zaman matematiğe yönelik tutumlarının olumlu etkilendiği söylenebilir.

Tablo 13'de Wilcoxon işaretli sıralar testi ile İran deney grubuna dair öntest-sontest tutum puanlarını gösteren tablo sunulmuştur.

Tablo 4: İran 10. Sınıf Deney Grubu Öğrencilerinin Tutum Ölçeği Puanlarına İlişkin Wilcoxon Testi

\begin{tabular}{ccccccc}
\hline Puan & Siralar & $\mathrm{n}$ & S.O & S.T & Z & $\mathrm{p}$ \\
\hline \multirow{2}{*}{ İr Deney Grubu Tutum } & Negatif Siralar & 7 & 9.64 & 67.50 & -3.089 & 0.002 \\
& Pozitif Siralar & 21 & 16.12 & 338.50 & & \\
Sontest- Öntest & Esit & 0 & & & & \\
& Toplam & 28 & & & & \\
\hline
\end{tabular}

Tablo 13'teki Wilcoxon testi sonuçlarına göre, İran deney grubunda öntest tutum puanına göre sontest tutum puanını düşüren öğrenci sayısı, sıra ortalaması puanları $\mathrm{N}=7, \mathrm{~S} . \mathrm{O}=9.64 \mathrm{iken}$, öntest tutum puanına göre sontest tutum puanını artıran öğrenci sayısı, sıra ortalaması puanları $\mathrm{N}=21, \mathrm{~S} . \mathrm{O}=16.12$ olarak ortaya çıkmıştır. Öntest-sontest puanları değişmeyen öğrenci sayısı ise iki öğrenci olarak $\mathrm{N}=0$ bulunmuştur. Bu bağlamda, İran deney grubu öğrencilerinin matematik tutum puanlarının sıra ortalamaları arası farklılığın anlamlı olup olmadığına bakıldığında; Z=-3.089; $\mathrm{p}<0.05$, deney grubu öğrencileri matematik dersi tutum puanları açısından karşılaştırıldığında sontest lehine anlamlı bir farklılık olduğu görülmüştür. Tablo 13'teki pozitif ve negatif sıra ortalamalarına bakıldığında; İran 10. sınıf deney grubu öğrencilerinin pozitif sıra ortalama puanı negatif sıra ortalama puanından fazla olduğundan hareketle, deney grubu öğrencilerinin matematik dersinde DMÖN'leri kullandıkları zaman matematiğe yönelik tutumlarının olumlu etkilendiği söylenebilir.

\section{Türkiye-İran Deney Gruplarının Tutum Puanları Arasındaki Farklılık}

Bu başlık altında; Türkiye ve İran deney gruplarının öntest tutum puanları arasında anlamlı bir farklılık olmadığı için, iki ülkenin deney gruplarının sontest tutum puanları üzerinden 
anlamlılığı analiz edilmiştir. Tablo 14'te Türkiye ve İran deney grubu öğrencilerinin sontest puanlarına dair istatistiksel veriler sunulmuştur.

Tablo 5: Türkiye-İran 10. Sınıf Deney Grubu Öğrencilerinin Sontest Tutum Puanlarına İlişkin Mann Whitney-U Sonuçları

\begin{tabular}{cccccc}
\hline Gruplar & $\mathrm{n}$ & Sira Ortalamas1 & Sira Toplamı & $\mathrm{U}$ & $\mathrm{p}$ \\
\hline Tr Deney Grubu & 28 & 25.50 & 722.50 & 316.50 & 0.215 \\
İr Deney Grubu & 28 & 31.20 & 873.50 & & \\
\hline
\end{tabular}

Tablo 14'teki Mann Whitney-U testi sonuçlarına göre, Türkiye deney grubu öğrencilerinin matematik dersinden aldıkları sontest tutum puanı sıra ortalaması $\mathrm{SO}_{\mathrm{D}}=25.50 \mathrm{iken}$, İran deney grubu öğrencilerinin matematik dersinden aldıkları sontest tutum puanı sira ortalaması $\mathrm{SO}_{\mathrm{K}}=31.20$ olarak bulunmuştur. Sıra ortalamaları arası farklılığın anlamlı olup olmadığına bakıldığında $\mathrm{U}=316.50 ; \mathrm{p}>0.05$, Türkiye ve İran deney grubu öğrencilerinin matematik dersi sontest tutum puanı açısından anlamlı bir fark olmadığı söylenebilir.

\section{DMÖN Uygulamalarının Derse Katılıma Etkisi}

Bu bölümde; Türkiye ve İran deney gruplarının öntest-sontest sıra ortalaması puanları arasındaki değişimin anlamlı olup olmadığını tespit etmek için Wilcoxon işaretli sıralar testi kullanılmıştır. Tablo 15 'de Wilcoxon işaretli sıralar testi ile Türkiye deney grubuna dair öntestsontest derse katılım puanlarını gösteren tablo sunulmuştur.

Tablo 6: Türkiye 10. Sınıf Deney Grubu Öğrencilerinin Derse Katılım Ölçeği Puanlarına İlişkin Wilcoxon Testi

\begin{tabular}{ccccccc}
\hline Puan & Sıralar & $\mathrm{n}$ & S.O & S.T & Z & $\mathrm{p}$ \\
\hline \multirow{2}{*}{ Tr Deney Grubu Derse Katılım } & Negatif Siralar & 8 & 9.50 & 76.00 & -2.892 & 0.004 \\
& Pozitif Sıralar & 20 & 16.50 & 330.00 & & \\
Sontest- Öntest & Eşit & 0 & & & & \\
& Toplam & 28 & & & & \\
\hline
\end{tabular}

Tablo 15'teki Wilcoxon testi sonuçlarına göre, Türkiye deney grubunda öntest tutum puanına göre sontest derse katılım puanını düşüren öğrenci sayısı, sıra ortalaması puanları $N=8$, $\mathrm{S} . \mathrm{O}=9.50$ iken, öntest tutum puanına göre sontest tutum puanını artıran öğrenci sayısı, sıra ortalaması puanları $\mathrm{N}=20, \mathrm{~S} . \mathrm{O}=16.30$ olarak ortaya çımıştır. Öntest-sontest puanları değişmeyen öğrenci sayısı ise iki öğrenci olarak $\mathrm{N}=0$ bulunmuştur. $\mathrm{Bu}$ bağlamda, Türkiye deney grubu öğrencilerinin matematik tutum puanlarının sıra ortalamaları arası farklılı̆̆ın anlamlı olup olmadığına bakıldığında; $\mathrm{Z}=-3.089 ; \mathrm{p}<0.05$, deney grubu öğrencileri matematik dersine katılım puanları açısından karşılaştırıldığında sontest lehine anlamlı bir farklılık olduğu görülmüştür. Tablo 15 'teki pozitif ve negatif sıra ortalamalarına bakıldığında; Türkiye 10. sınıf deney grubu öğrencilerinin pozitif sıra ortalama puanı negatif sıra ortalama puanından fazla olduğundan hareketle, deney grubu öğrencilerinin matematik dersinde DMÖN'leri kullandıkları zaman derse katılımlarının olumlu etkilendiği söylenebilir.

Tablo 16 'de Wilcoxon işaretli suralar testi ile İran deney grubuna dair öntest-sontest derse katılım puanlarını gösteren tablo sunulmuştur. 
Tablo 7: İran 10. Sınıf Deney Grubu Öğrencilerinin Derse Katılım Ölçeği Puanlarına İlişkin Wilcoxon Testi

\begin{tabular}{ccccccc}
\hline Puan & Siralar & $\mathrm{n}$ & S.O & S.T & Z & $\mathrm{p}$ \\
\hline \multirow{2}{*}{ İr Deney Grubu Derse Katılım } & Negatif Siralar & 2 & 7.00 & 14.00 & -4.206 & 0.001 \\
& Pozitif Siralar & 25 & 14.56 & 364.00 & & \\
& Eşit & 1 & & & & \\
& Toplam & 28 & & & & \\
\hline Sontest- Öntest & & & & & & \\
&
\end{tabular}

Tablo 16'daki Wilcoxon testi sonuçlarına göre, İran deney grubunda öntest tutum puanına göre sontest derse katılım puanını düşüren öğrenci sayısı, sıra ortalaması puanları $\mathrm{N}=2, \mathrm{~S} . \mathrm{O}=7.00$ iken, öntest tutum puanına göre sontest tutum puanını artıran öğrenci sayıs1, sıra ortalamas1 puanları $\mathrm{N}=25, \mathrm{~S} . \mathrm{O}=14.56$ olarak ortaya çıkmıştır. Öntest-sontest puanları değişmeyen öğrenci sayıs1 ise iki öğrenci olarak $\mathrm{N}=1$ bulunmuştur. $\mathrm{Bu}$ bağlamda, İran deney grubu öğrencilerinin matematik tutum puanlarının sira ortalamaları arası farklılığın anlamlı olup olmadığına bakıldığında; $Z=-4.206 ; p<0.05$, deney grubu öğrencileri matematik dersine katılım puanları açısından karşılaştırıldığında sontest lehine anlamlı bir farklılık olduğu görülmüştür. Tablo 16'daki pozitif ve negatif sıra ortalamalarına bakıldığında; İran 10. sınıf deney grubu öğrencilerinin pozitif sıra ortalama puanı negatif sıra ortalama puanından fazla olduğundan hareketle, deney grubu öğrencilerinin matematik dersinde DMÖN'leri kullandıkları zaman derse katılımlarının olumlu etkilendiği söylenebilir.

\section{Türkiye-İran Deney Gruplarının Derse Katılım Puanları Arasındaki Farklılık}

$\mathrm{Bu}$ başlık altında; Mann Whitney-U testi sonuçlarına göre, Türkiye ve İran deney gruplarının öntest derse katılım puanları arasında anlamlı bir farklılık olmadığı için, iki ülkenin deney gruplarının sontest derse katılım puanları üzerinden anlamlılığı analiz edilmiştir. Tablo 17 'de Türkiye ve İran deney grubu öğrencilerinin sontest puanlarına dair istatistiksel veriler sunulmuştur.

Tablo 8: Türkiye-İran 10. Sınıf Deney Grubu Öğrencilerinin Sontest Derse Katılım Puanlarına İlişkin Mann Whitney-U Sonuçları

\begin{tabular}{cccccc}
\hline Gruplar & $\mathrm{n}$ & Sira Ortalamas1 & Sira Toplamı & $\mathrm{U}$ & $\mathrm{p}$ \\
\hline Tr Deney Grubu & 28 & 26.73 & 748.50 & \multirow{2}{*}{342.50} & 0.417 \\
İr Deney Grubu & 28 & 30.27 & 847.50 & & \\
\hline
\end{tabular}

Tablo 17'deki Mann Whitney-U testi sonuçlarına göre, Türkiye deney grubu öğrencilerinin matematik dersinden aldıkları sontest derse katılım puanı sıra ortalamas $\mathrm{SO}_{\mathrm{D}}=26.73$ iken, İran deney grubu öğrencilerinin matematik dersinden aldıkları sontest derse katılım puanı sıra ortalaması $\mathrm{SO}_{\mathrm{K}}=30.27$ olarak bulunmuştur. Sıra ortalamaları arası farklılığın anlamlı olup olmadığına bakıldığında $U=342.50 ; p>0.05$, Türkiye ve İran deney grubu öğrencilerinin matematik dersi sontest derse katılım puanı açısından anlamlı bir fark olmadığı söylenebilir.

\section{Tartışma, Sonuç ve Öneriler}

\section{DMÖN'lerle Yapılan Uygulamaların Akademik Başarıya Etkisi}

Birinci araştırma sorusu kapsamında Mathematica yazılımı kullanılarak hazırlanan DMÖN'lerin öğrencilerin matematik dersi akademik başarı puanlarına etkisi ile ilgili bulgular tartışılmıştır. Çalışmada Türkiye-İran deney ve kontrol grupları üzerinde uygulanan sontest akademik başarı sıra ortalaması puanları istatistiksel olarak karşılaştırılmıştır. Bu karşılaştırmalarda her ülkenin deney ve kontrol gruplarının sıra ortalama puanlarının fark anlamlılığı dikkate alınmıştır. Bu açıdan bakıldığında; Türkiye 10. sınıf deney grubu öğrencilerinin sıra ortalama 
puanlarının kontrol grubu sıra ortalamasından fazla olduğuna ve akademik başarılarının kontrol grubuna göre olumlu etkilendiğine saptanılmıştır. Aynı bulgular İran 10. sınıf deney ve kontrol grupları için de geçerli olmuştur.

Analizlerde her iki ülkenin deney grubu öğrencilerinden akademik başarılarının olumlu etkilenmesine dair bulgular elde edilmiştir. Alanyazında bu sonucu destekleyen çalışmalarda, öğrencilerin matematik dersini DMÖN'lerle öğrendikleri zaman ön yargılarının ortadan kalkması, matematiğin sevimli bir ders haline dönüşmesi (Karaman vd., 2007; Lavicza \& Papp-Varga, 2010), soyut kavramların somutlaşması (Kutluca \& Baki, 2013a; Hatısaru \& Erbaş, 2013; Zehir, 2010), eğlenceli ve aktif bir matematik ders ortamının yaratılması ve yaparak yaşayarak öğrenme deneyimi sağlaması (Wei \& Ismail, 2010; Zengin, 2015) gibi faktörlerden dolayı matematik dersinde öğrencilerin akademik başarılarının artmasına sebep olduğu söylenebilir. DMÖN'lerin gelişmiş grafik çizebilme yetenekleri sayesinde, öğrenciler matematiğin soyut kavramlarını somut bir şekilde öğrenebilirler (Yavuz \& Kepceoğlu, 2010). Ayrıca DMÖN'lerde örnek sayısının sınırsız olması öğrencilerin kısa sürede fazla problem çözmelerine ve kalıcı öğrenmelerine imkan tanımaktadır (Kağızmanlı vd., 2013; Zengin, 2015).

\section{DMÖN'lein Öğrencilerin Matematik Dersine Yönelik Tutumlarına Etkisi}

Çalışmada Türkiye-İran deney grupları üzerinde uygulanan öntest-sontest tutum sıra ortalaması puanları istatistiksel olarak karşılaştırılmıştır. Karşılaştırma sonucunda; Türkiye 10. sınıf deney grubu öğrencileri matematik dersi tutum puanları açısından sontest lehine anlamlı bir farklılık olduğu görülmüştür. Aynı bulgular İran 10. sınıf deney grubu için de geçerli olmuştur. Analizlerde her iki ülkenin deney grubu öğrencilerinden matematik dersine yönelik tutumlarının olumlu etkilenmesine dair önemli bulgular elde edilmiştir.

Alanyazında bu sonucu destekleyen çalışmalarda, öğrencilerin matematik dersini DMÖN'lerle öğrendikleri zaman matematiğe yönelik ön yargılarının ortadan kalkması (Aşkar, 1986; Aktümen \& Kaçar, 2008), matematiğin eğlenceli bir derse dönüşmesi (Ardıç \& İşleyen, 2017; Aydoğdu \& Tutak, 2014), çeşitli grafik çizebilme özelliği sonucunda soyut kavramların somutlaştırılması (Aydoğdu, Erşen \&Tutak, 2014; Badeleh, 2017) ve matematik ders saatlerinin sıkıcı ortamdan eğlenceli bir ortam şekline dönüştürmesi gibi faktörlerden dolayı matematik dersine yönelik öğrencilerin tutumlarının artmasına sebep olduğu değerlendirilmektedir (Çankaya \& Karamete, 2008; Güler \& Sağlam, 2002; Zarrabian, 2018).

\section{DMÖN’lerin Öğrencilerin Matematik Dersine Yönelik Katılımına Etkisi}

Üçüncü araştırma sorusu kapsamında Mathematica yazılımı kullanılarak hazırlanan DMÖN'lerin öğrencilerin matematik dersine yönelik katılım puanlarına etkisi ile ilgili bulgular tartışılmıştır. Çalışmada Türkiye-İ́ran deney grupları üzerinde uygulanan öntest-sontest derse katılım sıra ortalaması puanları istatistiksel olarak karşılaştırılmıştır. Bu karşılaştırmalarda her ülkenin deney gruplarının sıra ortalama puanlarının fark anlamlılığı dikkate alınmıştır. Bu açıdan bakıldığında; Türkiye 10. sınıf deney grubu öğrencileri matematik dersine katılım puanları açısından karşılaştırıldığında sontest lehine anlamlı bir farklılık olduğu görülmüştür. Aynı bulgular İran 10. sınıf deney grubu için de geçerli olmuştur.

Analizlerde her iki ülkenin deney grubu öğrencilerinden matematik dersine yönelik katılımlarının olumlu etkilenmesine dair önemli bulgular elde edilmiştir. Alanyazında bu sonucu destekleyen çalışmalarda, öğrencilerin matematik dersini DMÖN'lerle öğrendikleri zaman matematiğe yönelik motivasyonlarının artması (Alessi \& Trollip, 2001; Badeleh, 2017), işlenilen konular hakkında gruplu fikir birliği yapabilmesi (Açıkgöz, 2014; Hıdıroğlu, 2014), gruplu öğrenmelerine kolaylık sağlanması (Badeleh, 2017; Çankaya \& Karamete, 2008) ve çalışma ortamının eğlenceli olması gibi faktörlerden dolayı matematik dersine yönelik katılımlarının artmasına sebep olması söylenebilir (Ardıç \& İşleyen, 2017; Hıdıroğlu, 2014; Zarrabian, 2018). 


\section{Sonuç}

Bu araştırmada DMÖN'lerin Türkiye ve İran 10. sınıf öğrencilerinin akademik başarılarına, tutumlarına ve derse katılımlarına etkisi incelenmiştir. Her iki ülkenin DMÖN'lerle eğitim gören deney grubu öğrencilerinden toplanan verilerin analizleri ve yapılan görüşlerden ortaya çıkan sonuçlar aşağıda sunulmuştur.

DMÖN'lerle eğitim gören Türkiye ve İran deney grubu öğrencilerinin akademik başarı puanları, kontrol gruplarına göre daha fazla olduğu ortaya çıkmıştır. Deney grubu öğrencilerinin DMÖN'lerle çalıştıkları zaman ön yargılarının ortadan kalkması, eğlenceli bir ders ortamının oluşması, görselleştirme özelliği ile soyut kavramların somutlaşması sonucunda akademik başarılarının olumlu etkilenmesine sebep olduğuna neden olmuşur.

Türkiye deney grubu öğrencilerinin tutum puanları arasında anlamlı bir fark olduğu belirtilmiştir. Öğrencilerin DMÖN'leri kullandıklarında, ders ortamının eğlenceli olması, soyut kavramların somutlaşması ve sürekli yeni örnekler çözebilme neticesinde matematik dersine yönelik tutumlarının olumlu etkilendiği söylenmiştir.

İran deney grubu öğrencilerinin tutum puanları arasında anlamlı bir fark olduğu belirtilmiştir. Öğrencilerin DMÖN'leri kullandıklarında, eğlenerek öğrenmeleri, görsel materyallerin sunulması ve örnek çeşitliği gibi faktörlerden dolayı matematik dersine yönelik tutumlarının olumlu etkilendiği ortaya çıkmıştır.

Türkiye deney grubu öğrencilerinin derse katılım puanları arasında anlamlı bir fark olduğu belirtilmiştir. Öğrencilerin DMÖN'leri kullandıklarında, gruplu çalıma ve fikir paylaşımı ve yaparak öğrenmelerine imkân sağlaması neticesinde matematik dersine yönelik katılımlarının olumlu etkilendiği söylenmiştir.

İran deney grubu öğrencilerinin derse katılım puanları arasında anlamlı bir fark olduğu belirtilmiştir. Öğrencilerin DMÖN'leri kullandıklarında, motivasyonlarının artması, görsel grafiklerin kullanılması ve ders ortamının eğlenceli olması gibi faktörlerden dolayı matematik dersine yönelik katılımlarının olumlu etkilendiği belirtilmiştir.

\section{Uygulayıcılara Yönelik Öneriler}

Çalışmada DMÖN'lerin Türkiye ve İran deney grupları üzerinde akademik başarılarını olumlu etkilediği için matematiğin diğer müfredatında da kullanılması önerilmektedir.

Çalışmada tutum ölçeği puanları açısından Türkiye ve İran deney grupları arasında anlamlı bir fark ortaya çıkmamıştır. Hazırlanan DMÖN'lerin zorluk ve kullanılabilirlik açısından hedef kitlenin teknoloji kullanım düzeylerine uygun olmalıdır. $\mathrm{Bu}$ yüzden; benzeri uygulamalarda öğrencilerin içerikle meşgul olup olmadıkları takip edilmeli ve öğrencilerin BT araçlarını amacının dışında kullanmalarına izin verilmemelidir.

$\mathrm{Bu}$ çalışmada uygulamaların yapılması için seçilen sınıfların yeterince BT altyapısına uymadığından dolayı bir takım sınırlılıklarla karşılaşılmıştır. Bu yüzden benzeri uygulamaların bilgisayar laboratüvarlarında yapılması önerilebilir.

\section{Kaynakça}

Açıkgöz, K. Ü. (2014). Aktif öğrenme. Biliş gelişimin Coşkusu.

Adıgüzel, T., Gürbulak, N. \& Sarıçayır, H. (2011). Akıllı tahtalar ve öğretim uygulamaları. Mustafa Kemal Üniversitesi Sosyal Bilimler Enstitüsü Dergisi, 15 (8), 457-471.

Aktümen, M. \& Kaçar, A. (2008). Bilgisayar cebiri sistemlerinin matematiğe yönelik tutuma etkisi. Hacettepe Üniversitesi Eğitim Fakültesi Dergisi, 35, 13-26. 
Alessi, S. M. \& Trollip, S. R. (2001). Multimedia for learning (3th edt.). Boston, MA: Allyn and Bacon.

Ardıç, M. A. \& İşleyen, T. (2017). Secondary school mathematics teachers' and students' views on computer assisted mathematics instruction in turkey: mathematica example. Malaysian Online Journal of Educational Technology, 5 (1).

Aşkar, P. (1986). Matematik dersine yönelik tutumu ölçen likert tipi bir ölçeğin geliştirilmesi. Eğitim ve Bilim, 11(62), 31 -36.

Ardıç, M. A. \& İşleyen, T. (2017). Secondary school mathematics teachers' and students' views on computer assisted mathematics instruction in turkey: mathematica example. Malaysian Online Journal of Educational Technology, 5 (1).

Aydın, B. \& Doğan, M. (2012). Matematik öğretimi: Geçmişten günümüze matematik önündeki engeller. Batman Üniversitesi Yaşam Bilimleri Dergisi, 1(2), 89-95.

Aydoğdu, M., Erşen, A. N. \& Tutak, T. (2014). Materyal destekli matematik öğretiminin ortaokul 6.sınıf öğrenci başarısına ve tutumuna etkisi. Turkish Journal of Educational Studies, 1(3), $166-185$

Badeleh, A. (2017). The impact of electronic content and workshop teaching on learning and retention of mathematics. Quarterly of Educatinal Psychology Allameh Tabataba'i University, 13(44).

Baki, A. (2002). Öğrenen ve ögrretenler için bilgisayar destekli matematik. Ceren Yayınları.

Baki, A (2015). Kuramdan uygulamaya matematik eğitimi. Harf Eğitim Yayınc1lı.

Baki, A. \& Çakıroğlu, Ü. (2010). Learning objects in high school mathematics classrooms: implementation and evaluation. Computers \& Education, 55(1459-1469).

Bell, A. \& Janvier, C. (1981). The interpretation of graphs representing situations. For the Learning of Mathematics, 2(1), 34-42.

Bulut, S. (2004). Illköğretim programi yeni yaklaşımlar matematik (1-5. Sınıf). Milli Eğitim Yayınları, Ankara.

Buteau, C. \& Mgombelo, J. (2012). Learnıng mathematıcs needed for teaching through designing, implementing and testing learning objects. IUMPST: The Journal.Vol3Technology, ISSN 2165-7874.

Capraro, M. M., Kulm, G. \& Capraro, R. M. (2005). Middle grades: Misconceptions in statistical thinking. School Science and Mathematics, 105(4), 165-174.

Çakıroğlu, Ü., Sarı, E. \& Akkan, Y. (2011). The view of the teachers about the contribution of teaching programming to the gifted students in the problem solving. Paper presented at 5th International Computer \& Instructional Technologies Symposium, Firat University, Elazı̆̆.

Chen, P. \& Zimmerman, B. (2007). A cross-national comparison study on the accuracy of selfefficacy beliefs of middle-school mathematics students. The Journal of Experimental Education, 75(3), 221-244.

Conceiçao, A. C.; Pereira, J. C.; Simao, C. R. \& Silva, C. M. (2012). Mathematica in the classroom: new tools for exploring precalculus and differential calculus. Conferance national Sobre computing symbolic Ensino e na İnvestigation, Lisboa,2-3.

Creswell, J. W. (2002). Educational research: planning, conducting, and evaluating quantitative and qualitative research. Upper Saddle River, NJ: Prentice Hall. 
Creswell, J. W. (2008). Educational research planning, conducting and evaluating quantitative and qualitative research. International Pearson Merril Prentice Hall.

Çubukçu, Z. \& Demirca, Z.A. (2019). Entegre program modeline göre tasarlanan bir dersin uygulanabilirlik ve etkililik yönünden değerlendirilmesi. Eskişehir Osmangazi Üniversitesi Türk Dünyası Uygulama ve Araştırma Merkezi ESTÜDAM Ĕ̈itim Dergisi,4(1).

Dedeoğlu, N. Ç., Agaç, G., Erdoğan, G. \& Koçak, C. (2013). MEB destekli sanal öğrenme nesnelerinin matematik öğretiminde etkili teknoloji kullanımı bağlamında incelenmesi. Bayburt Üniversitesi Ĕ̈itim Fakültesi Dergisi, 3(2).

Doll, W. J., Xia, W. \& Torkzadeh, G. (1994). A confirmatory factor analysis of the end-user computing satisfaction instrument. MIS quarterly, 18(4), 453-461.

Dunham, P. H. \& Osborne, A. (1991). Learning How To See: Students Graphing Difficulties. Focus on Learning Problems in Mathematics, 13(4), 35-49.

Ellis, A. B. \& Grinstead, P. (2008). Hidden lessons: how a focus on slope-like properties of quadratic functions encouraged unexpected generalizations. The Journal of Mathematical Behavior, 27(277-296).

Even, R. (1998). Factors involved in linking representations of functions. Journal of Mathematical Behavior, 17(1), 105-121.

Fonseca, L.M., Medeiros, J. M., Goes, F.S., Amorim, N. E. \& Scochi, C. G., (2012). Evaluation of the digital learning object taking care of the sensory enviroment in neonatal units: noise, light and handling. Procedia- Social Behavioral Sciences 46 (509-514).

Frenkel, E. (2013). Love and math: the heart of hidden reality. NY: Basic Books.

Fraenkel, J., Wallen, N. \& Hyun, H. H. (2012). How to design and evaluate research in education (8th ed.). Boston: McGraw Hill.

Ghosh, J. B. (2011). Exploring fourier series and gibbs phenomenon using mathematica. Australian Senior Mathematics Journal, 25 (1).

Gök, G. \& Erbilgin, E. (2012). Öğrenme nesneleriyle toplama oyunu. Araştırma Temelli Etkinlik Dergisi (ATED), 2(1), 10-18.

Gülcü, A. (2004). Mathematica 5 bilgisayar destekli matematik. Nobel Yayın Dağıtım.

Güler, M. H. \& Sağlam, N. (2002). Biyoloji öğretiminde bilgisayar destekli öğretimin ve çalışma yapraklarının öğrencilerin başarısı ve bilgisayara karşı tutumlarına etkisi. Hacettepe Üniversitesi Eğitim Fakültesi Dergisi, 23, 117-126.

Günüç, S., Odabaşı, H.F. \& Kuzu, A. (2013). 21. Yüzyıl öğrenci özelliklerinin öğretmen adayları tarafindan tanımlanmas1: bir twitter uygulaması. Eğitimde Kuram ve Uygulama, 9(4), 436455.

Hatısaru, V. \& Erbaş, A. K. (2013). Endüstri meslek lisesi öğrencilerinin fonksiyon kavramini anlama düzeylerinin incelenmesi. Kastamonu Eğitim Dergisi, 21(3), 865-882.

Heid, M.K. (1997). The technological revolution and the reform of school mathematics. American Journal of Education, 106, 5-61.

Hereman, W. (1996). The incredible world of symbolic mathematics a review of computer algebra systems. 
Hıdıroğlu, F. M. (2014). The role of perceived classroom goal structures, self-efficacy, and student engagement in seventh grade students' science achievement. [Unpublished master's thesis]. Middle East Technical University.

İçel, R. (2011). Bilgisayar destekli ögretimin matematik başarısına etkisi: geogebra örneği. [Yüksek Lisans Tezi]. Selçuk Üniversitesi.

Işıksal, M. \& Aşkar, P. (2003). Elektronik tablolama ve dinamik geometri yazılımını kullanarak çalışma yapraklarının geliştirilmesi. İlkögretim-Online, 2 (2), 10-18.

Jacobus, B. \& Podeschi, R. (2018). Low-cost cluster computing using raspberry pi with mathematica. Information Systems Education Journal (ISEDJ), 16 (6).

Johnson, S. D. \& Aragon, S. R. (2003). An instructional strategy framework for online learning environments. New Directions for Adult and Continuing Education, 100(31-43).

Kacar, A. \& Doğan, N. (2007). Okulöncesi eğitimde bilgisayar destekli eğitimin rolü. Akademik Bilişim Konferansı, Dumlupınar Üniversitesi.

Kağızmanlı, T. B., Tatar, E. \& İşleyen, T. (2013). Bilgisayar destekli matematik öğretimi dersinde dinamik matematik yazılımının kullanımı. Mustafa Kemal Üniversitesi Sosyal Bilimler Enstitüsü Dergisi, 23(167-180).

Karaman, S.; Özen, Ü. \& Yıldırım, S. (2007). Pedagogical features and integration of learning objects into learning environments. Education and Science, 32(145).

Karademirci, A.H. (2010). Öğretim teknolojileri: tanımı ve tarihsel gelisimine yeniden bakmak. Middle East Technical University, Computer Education and Instructional Technologies, Ankara.

Karasar, N. (1999). Bilimsel Araştırma Yöntemi (9. Baskı).Nobel Yayın Dağıtım.

Kaymakçı, S. (2010). Sosyal bilgiler öğretiminde çalışma yaprakları kullanımının öğrencilerin akademik başarılarına ve derse karşı tutumlarına etkisi. Doktora tezi. Gazi üniversitesi, Ankara.

Kelsey, J. S., Carl, E. R. \& Holly, A. T. (2004). Improving computer-assisted instruction in teaching higher-order skills. Computers and Education, 42.

Kieran, C. (1992). The learning and teaching of school algebra. In d. Grouws (ed.), handbook of research on mathematics teaching and learning (pp. 390-419). NewYork: Macmillan Publishing Company.

Kutluca, T. \& Baki, A. (2009). 10. Sinıf matematik dersinde zorlanılan konular hakkında öğrencilerin, öğretmen adaylarının ve öğretmenlerin görüşlerinin incelenmesi. Kastamonu Üniversitesi Kastamonu Eğitim Dergisi, 17 (2), 616-632.

Kutluca, T. \& Baki, A. (2013a). Elektronik tablolama ve bilgisayar cebir sistemi yardımıyla bilgisayar destekli çalışma yapraklarının geliştirilmesi. Eğitimde Kuram ve Uygulama, 9(4), 511-528.

Lannie, A. L. \& Martens, B. K. (2004). Effects of task difficulty and type of contingency on students' allocation of responding to math worksheets. Journal of Applied Behavior Analysis, 37 (1), 53-65.

Lavicza, Z. \& Papp-Varga, Z. (2010). Integrating geogebra into iwb-equipped teaching environments: preliminary results. Technology Pedagogy and Education,19(2),245-252. 
Leinhardt, G., Zaslavsky, O. \& Stein, M. K. (1990). Functions, graphs, and graphing: tasks, learning, and teaching. Review of Educational Research, 60(1),1-64.integration through lesson planning practice. Computers \& Education, 73, 121-128.

MEB. (2011). MEB 21. yüzyıl öğrenci profili, http://www.meb.gov.tr/earged/earged/21. \%20yy_og_pro.pdf

MEB. (2019). Ortaöğretim matematik (9, 10, 11 ve 12. Sınıflar) dersi öğretim programı. Ankara: Milli Eğitim Bakanlığı.

Moyer, P.S. (2001). Are we having fun yet? How teachers use manipulatives to teach mathematics. Educational Studies in Mathematics, 47, 175-197.

Özerbaş, M. A. \& Çiçek, A. S. (2014). Effect of online learning objects on academic achievement and transfer skills. Hacettepe Üniversitesi Eğitim Fakültesi Dergisi (H. U. Journal of Education), 29(1), 196-210.

Özerbaş, M. A. \& Kılıç, T. B. (2017). The effects of using learning objects on the students' achievement, motivation and persistence in mathematics teaching. Kastamonu Ĕ̈itim Dergisi, 975-992, 25(3).

Peeraer, J. \& Van Petegem, P. (2012). Measuring integration of information and communication technology in education: an item response modeling approach. Computers \& Education, 58(4), 1247-1259.

Ramani, R. \& Patadia, H. (2012). Computer assisted instruction in teaching of mathematics. IOSR Journal of Humanities and Social Science (JHSS), 2, 39-42.

Reeve, J. \& Tseng, C. M. (2011). Agency as a fourth aspect of students' engagement during learning activities. Contemporary Educational Psychology, 36(4), 257267.

Roblyer, M. D., Edwards, J. \& Havriluk, M. A. (2004). Integrating educational technology into teaching (4th ed.), Upper Saddle River, NJ: Prentice Hall.

Sarama, J. \& Clements, D. H. (2009). "Concrete" computer manipulatives in mathematics education. Child Development Perspectives, 3(3), 145-150.

Segars, A. H. \& Grover, V. (1993). Re-examining perceived ease of use and usefulness: a confirmatory factor analysis. MIS quarterly, 17(4), 517-525.

Selçik, N. \& Bilgici, G. (2011). Geogebra yazılımın öğrenci başarısına etkisi. Kastamonu Eğitim Dergisi, 19(3), 913-924.

Tatar, E., Akkaya, A. \& Kağizmanli, T. B. (2014). Using dynamic software in mathematics: the case of reflection symmetry. International Journal of Mathematical Education in Science and Technology, 45(7), 980-995.

Taşlıbeyaz, E. \& Gülcü, A. (2013). Secondary school students' views on computer assisted mathematics instruction. Journal of Theoretical Educational Science, 6(3), 408-422.

Tosun, N. (2006). Bilgisayar destekli ve bilgisayar temelli ögretim yöntemlerinin, ögrencilerin bilgisayar dersi başarısı ve bilgisayar kullanım tutumlarına etkisi.[Yayımlanmamış Doktora Tezi].Trakya Üniversitesi Eğitim Fakültesi.

Türel, Y. K. \& Gürol, M. (2009). Öğrenme nesnelerinin öğrenme boyutu. E-Journal of New World Sciences Academy, 4(1), Article Number: 1C0017, ISSN:1306-3111.

Türel, Y. K. \& Gürol, M. (2011). A comprehensive evaluation of learning objects-enriched instructional environments in science classes. Contemporary Educatıonal Technology, 2(4), 264-281. 
Tutak, T., Türkdoğan, A. \& Birgin, O. (2009). The effect of geometry teaching with cabri to learning levels of forth grade students. E-Journal of New World Sciences Academy, 4(2).

Uğurel, I. \& Bukova-Güzel, E. (2010). Matematiksel öğrenme etkinlikleri üzerine bir tartışma ve kavramsal bir çerçeve önerisi. Hacettepe Üniversitesi Ĕ̈itim Fakültesi Dergisi,39,333-347.

Uniform Resource Loader [URL] -1, (2017). Partnership for 21. Century learning. http://www.p21.org/our-work/p21-framework (Erişim tarihi 16.03.2018).

Uluyol, Ç. \& Eryılmaz, S. (2015). 21. Yüzyıl becerileri 1şı̆̆ında FATİH projesi değerlendirmesi. Gazi Üniversitesi Gazi Eğitim Fakültesi Dergisi, 35(2), 209-229.

Wei, C. S. \& Ismail, Z. (2010). Peer interactions in computer-supported collaborative learning using dynamic mathematics software. In R. A. Tarmizi and A. F. M. Ayub (Eds.), International Conference on Mathematics Education Research 8(600-608).

Yavuz, İ. \& Kepceoğlu, İ. (2010). Öğrencilerin fonksiyonlarda işlemler konusuna grafikler üzerinden yaklaşimlarinin incelenmesi. Sakarya Üniversitesi Eğitim Fakültesi Dergisi,20, 59-80.

Zarrabian, F. (2018). Examination of other myths on the principles of parenting on the teaching of mathematics lessons, third-elementary students. Journal of Research, 8(2).

Zazkis, R., Liljedahl, P., \& Gadowsky, K. (2003). Conceptions of function translation: obstacles, intuitions, and rerouting. The Journal of Mathematical Behavior, 22(4), 435-448.

Zbiek, R. M., Heid, M. K., Blume, G. W. \& Dick, T. P. (2007). Research on technology in mathematics education: the perspective of constructs. In F. Lester (Ed.), Handbook of research on mathematics teaching and learning (Vol. 2, pp. 1169-1207).

Zehir, H. (2010). Çalışma yaprakları ile lineer dönüşümler ve lineer dönüşümlere karşıllk gelen matrislerin ögretimi. [Yayımlanmamış Doktora Tezi]. Atatürk Üniversitesi.

Zengin, Y. (2015). Dinamik matematik yazılımı destekli işbirlikli ögrenme modelinin ortaögretim cebir konularının ögrenimi ve öğretiminde uygulanabilirliğinin incelenmesi. [Yayımlanmamış Doktora Tezi]. Atatürk Üniversitesi. 